\author{
Contato \\ BR 465 - Km 7 - ICHS/DHRI \\ 23890-000 - Seropédica - Rio de Janeiro - Brasil \\ E-mail: mdagoncalves@gmail.com
}

\section{A EDIFICAÇÃO DA CRISTANDADE NO ORIENTE PORTUGUÊS: QUESTÕES EM TORNO DA ORDEM DOS EREMITAS DE SANTO AGOSTINHO NO LIMIAR DO SÉCULO XVII}

\author{
Margareth de Almeida Gonçalves** \\ Universidade Federal Rural do Rio de Janeiro
}

\title{
Resumo
}

O artigo oferece elementos para um estudo da Ordem dos Eremitas de Santo Agostinho da Província de Portugal na segunda metade do século XVI e primeiras décadas dos Seiscentos. Para tanto, três eixos de abordagem são destacados e procuram orientar a reflexão acerca de conjunturas diversas: a reforma religiosa da Ordem dos Eremitas de Santo Agostinho e as conexões cortesãs nos Quinhentos; o papel dos agostinhos na construção dos dispositivos disciplinares após o Concílio de Trento (1543-1563); e a presença da ordem no Índico.

\section{Palavras-chave}

Eremitas de Santo Agostinho - Império português - Estado da Índia.

* Artigo escrito a partir do trabalho de pesquisa realizado no ICS-Universidade de Lisboa (outubro 2011/abril 2012), com o apoio da Capes. Sou extremamente agradecida a Ângela Barreto Xavier pela supervisão do estágio pós-doutoral e pela leitura e sugestões ao projeto de investigação. Ademais, sou grata à leitura e às sugestões dos pareceristas ad hoc da Revista de História.

** Pós-doutorado pela Universidade de Lisboa. Professora Associada II, Departamento de História e Relações Internacionais. 


\section{Contact} BR 465 - Km 7 - ICHS/DHRI 23890-000 - Seropédica - Rio de Janeiro - Brazil E-mail: mdagoncalves@gmail.com

\section{THE BUILDING OF \\ CHRISTIANITY IN \\ PORTUGUESE ORIENT:}

ISSUES ABOUT THE

HERMITS OF SAINT

AUGUSTINE IN THE

BEGINNING OF THE $17^{T H}$

CENTURY

\section{Margareth de Almeida Gonçalves}

Universidade Federal Rural do Rio de Janeiro

\begin{abstract}
This article offers elements for a study of the Order of Hermits of Saint Augustine in the Province of Portugal in the second half of the 16th century and first decades of the 17th century. For the purpose of analysis, three main approaches are highlighted to try to guide the reflection on diverse contexts: the reform of the religious Order of the Hermits of St. Augustine and the connections with the royal court in the 16th century; the role of the Augustinians in the construction of discipline after the Council of Trent (1543-1563); and the presence of the order in the Indian Ocean.
\end{abstract}

\title{
Keywords
}

Hermits of St. Augustine - Portuguese empire - Portuguese India. 
rev. hist. (São Paulo), n. 170, p. 107-141, jan.-jun., 2014 http://dx.doi.org/10.11606/issn.2316-9141.v0i170p107-141
Margareth de Almeida Gonçalves

A edificação da cristandade no Oriente português: questões em torno da Ordem dos Eremitas de Santo Agostinho no limiar do século XVII

A historiografia sobre a evangelização no Império ultramarino português na Época Moderna raramente contempla a Ordem dos Eremitas de Santo Agostinho. Apesar da renovação historiográfica da história das religiões nos últimos anos, ${ }^{1}$ a produção acerca dos agostinhos é de reduzida expressão. ${ }^{2}$ Com exceções pontuais, prevalece a ausência de análises e de estudos monográficos acerca da ação dos agostinhos nos territórios de além-mar. ${ }^{3}$ Entretanto, entre as abordagens, destaca-se o contributo das vertentes ligadas à erudição da tradição historiográfica crítica e positivista, em que predominam os estudos acerca da institucionalização dos estabelecimentos agostinhos e dos processos de conversão dos "gentios" em regiões da África e Ásia. ${ }^{4}$

1 Atente-se para a produção acerca de história das instituições religiosas e da espiritualidade em torno dos periódicos Lusitana Sacra e Via Spiritus. Em linhas gerais, cabe destacar na historiografia mais recente as seguintes publicações: MARQUES, João Francisco; GOUVEIA, António Camões (orgs.). Humanismo e reformas. In: AZEVEDO, Carlos Moreira (dir.). História religiosa de Portugal, vol. 2. Lisboa: Círculo dos Leitores, 2000, como ainda AZEVEDO, Carlos Moreira (dir.). Dicionário de história religiosa de Portugal. 3 volumes. Lisboa, Círculo de Leitores, 2000 e Idem. Dicionário de história religiosa de Portugal. 4 volumes. Lisboa: Círculo Leitores, 2000-2001.

2 Acerca do processo de reforma da Ordem dos Eremitas de Santo Agostinho da Província de Portugal, iniciado em 1535, no bojo das intervenções reformistas no campo religioso do reinado de d. João III (r. 1521-1557) e os reformismos do século XVI, remeto a: DIAS, José Sebastião da Silva. Correntes de sentimento religioso em Portugal (séculos XVI a XVIII), vol. I. Coimbra: Universidade de Coimbra, 1960; Idem. O erasmismo e a inquisição em Portugal: o processo de fr. Valentim da Luz. Coimbra: Universidade de Coimbra, 1975; FERNANDES, Maria de Lurdes. Da reforma da Igreja à reforma dos cristãos: reformas, pastoral e espiritualidade. In: MARQUES, João Francisco; GOUVEIA, António Camões. (orgs.), op. cit., p. 15-38.

3 No âmbito da produção historiográfica, sobressaem estudos acerca dos agostinhos nos espaços asiáticos na margem do Índico ocidental concentrados no período de quinze anos (1595-1610) do arcebispado em Goa do agostinho d. frei Aleixo de Meneses. Vejam-se: GULBENKIAN, Roberto. L'ambassade en Perse de Luis Pereira de Lacerda et des pères portugais de l'Ordre de Saint-Augustin, Belchior dos Anjos et Guilherme de Santo Agostinho 1604-1605. Lisboa: Fundação Calouste Gulbenkian, 1972; SUBRAHMANYAM, Sanjay. Dom frei Aleixo de Meneses (1559-1617) et l'échec des tentatives d'indigénisation du christianisme en Indie. Archives des Sciences sociales des religions. Paris, 1998, p. 21-42, http://dx.doi.org/10.3406/assr.1998.1193; FLANNERY, John M. Religião, comércio, política, apostasia e polémica: uma visão geral da missão persa dos agostinhos portugueses (1603-1747). Oriente, Lisboa, $\mathrm{n}^{\circ}$ 19, 2008, p. 80-93; Idem. The mission of the Portuguese Augustinians to Persia and beyond (1602-1747). Leiden/Boston: Brill, 2013; BETHENCOURT, Francisco. As câmaras e as misericórdias. In: BETHENCOURT, Francisco e CHAUDHURI, Kirti. História da expansão portuguesa, vol. 3. Lisboa: Círculo de Leitores, 1998; Idem. Os conventos femininos no Império português. O caso do Convento de Santa Mónica em Goa. In: O rosto feminino da expansão portuguesa. Cadernos Condição Feminina, no 43, 1995; PINTO, Carla Alferes. Notas para o estudo do mecenato de d. frei Aleixo de Meneses: os recolhimentos da Misericórdia de Goa. Anais de História de Além-Mar, Lisboa, VII, 2006.

${ }^{4}$ Sobressai a produção do historiador agostinho espanhol Carlos Alonso, de vasta produção com ênfase na recolha de documentação, reiterando um dos legados do antiquarismo na história eclesiástica e história religiosa (parte da produção do historiador agostinho é assinalada ao longo deste artigo). Ao seu nome, somam-se os contributos de AZEVEDO, Carlos 
Em perspectiva geral, este artigo traz elementos que contemplam a fixação da Ordem dos Eremitas de Santo Agostinho no Índico nas três últimas décadas do século XVI e nos anos iniciais da centúria seguinte. Para tanto, contempla as implicações do movimento de reforma da ordem iniciado no reinado de d. João III (1521-1557) e a futura expansão dos agostinhos através dos vultos de d. frei Agostinho de Jesus (1537-1609), provincial da Ordem dos Eremitas de Santo Agostinho em Portugal, ao tempo do envio da primeira missão dos eremitas à Ásia, em 1572, e, posteriormente, quando ocupou a sede do arcebispado de Braga (1588-1609), e de d. frei Aleixo de Meneses (1559-1617), arcebispo de Goa entre 1595 e 1612. ${ }^{5}$ Ao período da integração do reino de Portugal na monarquia hispânica associa-se a presença dos dois antístites em arcebispados primazes do Império e o favorecimento da expansão dos eremitas nos espaços asiáticos no braço da Congregação da Índia Oriental. As trajetórias dos dois agostinhos demonstram o peso das relações palacianas nas carreiras eclesiásticas e no efeito robustecedor da ordem religiosa. Ademais, evidenciam os esforços de criação de uma rotina administrativa nos processos de centralização e fortalecimento da autoridade arcebispal, aspectos característicos do cenário pós-tridentino.

O ponto de partida deste artigo foi acionado pela leitura de um conjunto de manuscritos cuja autoria é atribuída ao religioso da Congregação da Índia Oriental da Província de Portugal dos eremitas de Santo Agostinho, frei Diogo de Santa Anna (1571-1644), que embarcou na mesma armada que passou à Índia com d. frei Aleixo de Meneses no provimento do arcebispado de Goa, em 1595. Frei Diogo permaneceu o restante dos 49 anos no Estado da Índia, com proeminência em duas ações notáveis dos agostinhos na primeira metade do século XVII: a passagem pelo priorado do Convento agostinho de Ispahan na cidade corte do xá Abbas I (1587-1629) da Pérsia, fundado em 1602, na condução das tentativas de redução da Igreja da Armênia à obediência ao papa em Roma e, logo depois, na função de confessor geral do

\footnotetext{
Moreira. Ordem dos Eremitas de Santo Agostinho em Portugal (1256-1834). Lisboa: Centro de Estudos de História Religiosa/ Universidade Católica Portuguesa, 2011 (Coleção de Memórias de frei Domingos Vieira, O.E.S.A.); de historiadores, também vinculados a ordens agostinhas, entre os quais HARTMAN, Arnulf. The Augustinians in Golden Goa. A manuscript by Felix of Jesus. O.S.A. Analecta Augustiniana, Roma, vol. XXX, 1967; LOPEZ, Teofilo Aparicio, O.S.A. La orden de san Agustin en la India. Valladolid: Ediciones Monte Casino, 1977. GUTIÉRREZ, David. Historia de la orden de San Agustin. 3 volumes. Roma: Institutum Historicum Ordinis Fratrum S. Augustini, 1971-1980.

5 Aleixo de Meneses parte de Goa ao final de 1610, embora respondesse pelo arcebispado até sua nomeação para a mitra de Braga em 1612.
} 
rev. hist. (São Paulo), n. 170, p. 107-141, jan.-jun., 2014 http://dx.doi.org/10.11606/issn.2316-9141.v0i170p107-141
Margareth de Almeida Gonçalves

A edificação da cristandade no Oriente português: questões em torno da Ordem dos Eremitas de Santo Agostinho no limiar do século XVII

mosteiro de freiras agostinhas de Goa. Em momentos diversos da escrita, frei Diogo de Santa Anna alude à incumbência delegada por d. frei Aleixo de Meneses de administrar o Mosteiro de Santa Mônica de Goa. Havia um vínculo forte entre os dois religiosos, conforme aludido em missiva do prócer arcebispo em 10 de outubro de 1611, enviada meses após deixar a ribeira de Goa no último dia do ano de 1610, para não mais retornar ao Oriente: "muito estou sentindo o trabalho, que V. R. há de ter com esse mosteiro, de que o deixei encarrregado". ${ }^{6}$

Ora, o mesmo frei Diogo de Santa Anna, em um de seus últimos escritos, do ano de 1637, no desfecho de uma longa década de crise, assolada pela contenda entre o Mosteiro de Santa Mônica e o Senado da Câmara de Goa, ${ }^{7}$ recorreu a "informações" de vida e genealogia familiar a fim "de não perder o bom nome e fama". ${ }^{8}$ Na sustentação do lugar de autoridade e marca de distinção, Santa Anna fez menção, não casualmente, ao fato do avô por linha paterna, Aleixo de Moraes Pimentel, ter sido vedor da fazenda da rainha d. Catarina (1507-1578), em meados dos Quinhentos. Não importa aqui que tenha alterado o ofício do avô, que não foi vedor, posição de maior proeminência fidalga, mas escrivão da fazenda. ${ }^{9}$ A breve menção ao avô desencadeia remotos vínculos parentais que têm por função advertir para uma dimensão

\footnotetext{
${ }^{6}$ Cf. BA, 47-VIII-15, fl. 459. Neste artigo, utilizo as seguintes abreviaturas de arquivos: Arquivo Nacional da Torre do Tombo (ANTT); Corpo Cronológico (CC); Manuscritos da Livraria (ML); Biblioteca da Ajuda (BA); Arquivo Distrital de Braga (AB); Biblioteca Pública e Arquivo Distrital de Évora (BPADE)

7 A queixa dos vereadores do poder municipal goês, formalizada em petição de 13 de fevereiro de 1632, enviada ao vice-rei da Índia, d. Miguel de Noronha, conde de Linhares, denunciava o Mosteiro de Santa Mônica e os agostinhos - na pessoa do administrador frei Diogo de Santa Anna - de isolar e concentrar as mulheres ricas do Estado da Índia, em época de carestia e de contínuas perdas nas constantes guerras que assolavam a parte oriental do Império de Portugal. Veja-se GONÇALVES, Margareth de Almeida. "Gloria de Deus, ao serviço do rei e ao bem desta Republica": freiras de Santa Mônica de Goa e a cristandade no Oriente pela escrita do agostinho frei Diogo de Santa Anna na década de 1630. História, São Paulo, v. 32, n. 1, 2013, p. 251-280, http://dx.doi.org/10.1590/s0101-90742013000100015.

${ }^{8}$ Cf. Informação dos poucos aprouvitamentos do pe. fr Diogo de Santa Anna, servo sem proveito, da Ordem dos Eremitas do patriarcha $S^{\text {to }}$ Agostinho, emissionario da Índia oriental. ANTT/ ML 674, fls. 65v, 66f. O relato sobre a vida, a trajetória e a genealogia tem redação na terceira pessoa, com o emprego do tempo fechado do verbo no pretérito perfeito do modo indicativo ou no infinitivo.

9 Cf. Informações que constam em alvará da rainha para se pagar a Aleixo de Morais, escrivão da fazenda, 128.200 réis de ordenados, ANTT/CC, parte I, maço 90, documento 63; Papel que deu o secretário de Estado Pedro Vieira da Silva sobre alguns ofícios da casa e fazenda das rainhas de Portugal, fl. 11f, BA, 51-VIII-29.
} 
rev. hist. (São Paulo), n. 170, p. 107-141, jan.-jun., 2014 http://dx.doi.org/10.11606/issn.2316-9141.v0i170p107-141
Margareth de Almeida Gonçalves

A edificaç̃ão da cristandade no Oriente português: questões em torno da Ordem dos Eremitas de Santo Agostinho no limiar do século XVII

nobiliárquica, indigitando uma conexão com a casa da rainha d. Catarina e os Habsburgo. Uma rápida lembrança que, ao se juntar a outros nomes de agostinhos com vínculos que recuam ao reinado de d. João III (1521-1557), oferecem indícios acerca da presença da Ordem dos Eremitas de Santo Agostinho nos espaços asiáticos nas três últimas décadas do século XVI e no início da centúria seguinte, na conformação da Congregação da Índia Oriental.

Por sua vez, registremos, com base na análise de Federico Palomo, o quadro de tensão entre as facções do poder eclesiástico e a nova dinastia, enfrentado por Filipe II, resultando nas concessões do monarca aos segmentos clericais. ${ }^{10}$ A escolha do sobrinho, cardeal arquiduque Alberto de Áustria, para vice-rei de Portugal reafirmou a repetição do modelo do tio, cardeal d. Henrique, durante a regência de d. Sebastião, que interpenetrou as instâncias religiosas e a monarquia. A estratégia de neutralizar a oposição eclesiástica conformou o acordo das Cortes de Tomar (1581), nas tentativas de isolamento dos partidários de d. Antonio, prior do Crato, que contava com preocupante apoio no episcopado e no clero regular. ${ }^{11}$

Lembre-se, ademais, que os bispos exerceram tanto um arrimo importante e legitimador de Filipe II como garantiram o disciplinamento das populações, aliando a prática pastoral ao governo da monarquia. ${ }^{12}$ José Pedro Paiva chama a atenção para a importância, na época filipina, da nomeação dos bispos junto aos que acolheram de prontidão a causa da nova dinastia, ou entre aqueles pertencentes a parentelas que prestaram serviços aos Áustria. Deste modo, destaca a importância de escolhas que remontavam a ligações clientelares com a casa de d. Catarina, entre as quais assinala os nomes de d. frei Agostinho de Jesus e d. frei Aleixo de Meneses, nomes proeminentes na Ordem dos Eremitas de Santo Agostinho ao final dos Quinhentos em Portugal. ${ }^{13}$

\footnotetext{
${ }^{10}$ Ao me referir a Filipe I de Portugal, utilizarei neste artigo a denominação espanhola do monarca, Filipe II. E o mesmo se aplica a Filipe II de Portugal, Filipe III de Espanha.

${ }^{11}$ Registrem-se as adesões ao partido antonino dos agostinhos frei Agostinho da Trindade ( c. 1595) e frei Miguel dos Santos (c. 1537-1595), o falso d. Sebastião de Madrigal. Vejam-se: MARQUES, João Francisco. Frei Miguel dos Santos e a luta contra a União Dinástica. O contexto do falso d. Sebastião do Madrigal. Revista da Faculdade de Letras, História, II série, vol. XIV, Porto, 1997, p. 331-377; HERMANN, Jacqueline. No reino do desejado. A construção do sebastianismo em Portugal nos séculos XVI e XVII. São Paulo: Companhia das Letras, 1998, p. 256-268.

${ }_{12}$ PALOMO, Federico. Para el sosiego y quietud del reino. En torno a Felipe II y el poder eclesiástico en el Portugal de finales del siglo XVI. Hispania, LXIV/1, n. 216, 2004, p. 63-93, http:// dx.doi.org/10.3989/hispania.2004.v64.i216.197.

${ }^{13}$ PAIVA, José Pedro. Os bispos de Portugal e do Império (1465-1777). Coimbra: Imprensa da Universidade de Coimbra, 2006, p. 377-379.
} 
Por seu turno, os dois agostinhos retiveram ligações de linhagem que recuavam ao reinado de d. João III, como também ocuparam arcebispados centrais na dinâmica eclesiástica do império, os quais favoreceram o enraizamento da província portuguesa dos agostinhos. Uma referência inesperada feita por frei Diogo de Santa Anna em 1637 põe em relevo o delineamento de um projeto monárquico de formato imperial no reinado de d. João III e que perdurou pelo século XVI, com desdobramentos no período dos dois primeiros Filipe de Portugal.

\section{Os eremitas de Santo Agostinho e o reinado de d. João III}

No reinado do Piedoso, conformaram-se espaços de imbricação entre as esferas eclesiástica e de governação. A construção de instrumentos de fortalecimento da autoridade real teve por corolário a criação de quadros administrativos que delinearam o ordenamento da monarquia de perfil confessional, a qual se sustentou na articulação com os segmentos letrados do clero. ${ }^{14}$

No processo de enquadramento disciplinar das ordens religiosas ${ }^{15}$ movido no reinado de d. João III, entre os eremitas de Santo Agostinho foram os espanhóis frei Francisco de Vilafranca (†1555) e frei Luís de Montoia (14971569) que conduziram o processo de reforma. ${ }^{16}$ Vilafranca, o primeiro em precedência da dupla, impeliu o reordenamento monástico no Convento de Nossa Senhora da Graça em Lisboa, cabeça da província portuguesa, através da ênfase numa espiritualidade de traços rigoristas, revivendo o ideal primitivo da ordem e produzindo um modelo com ênfase na austeridade e na acepção de ascese pietista de contornos quase místicos, matriz a ser reprodu-

\footnotetext{
${ }^{14}$ PALOMO, Federico. "Disciplina christiana". Apuntes historiográficos en torno a la disciplina y el disciplinamiento social como categorías de la historia religiosa de la alta edad moderna. Cuadernos de Historia Moderna, n. 18, 1997, p. 120, 121; Idem, 2004, op. cit., p. 64.

${ }^{15}$ A reforma das congregações religiosas no reinado de d. João III tem desdobramentos conhecidos: a anexação à Coroa das ordens militares, o labor reformista de diversas ordens - cistercienses, franciscanos, carmelitas, dominicanos, agostinhos. Consulte-se DIAS, José Sebastião da Silva, 1960, op. cit., vol. I, p. 99-136. A maior capacidade de intervenção da Coroa durante o reinado de d. João III é assinalada também por PALOMO, Federico. Fazer dos campos escolas excelentes. Os jesuítas de Évora e as missões do interior em Portugal (1551-1630). Lisboa: Fundação Calouste Gulbenkian/FCT, 2003, p. 61.

${ }^{16}$ MARQUES, José. Frei Luís de Montoia e Diogo de Castilho na construção do Colégio da Graça de Coimbra segundo o "Libro das obras del Collegio". Revista da Faculdade de Letras, Ciências e Técnicas do Património. Porto, série, 2008-2009, volume VII-VIII, p. 231-278; ROMO, Eduardo Javier Alonso. Agustinos portugueses que escribieron en castellano (1550-1700). Aula ibérica on line, 2010, tomo 1, http://www.filologiaportuguesa.es/aulaibericaActual2.asp?cod=4.
} 
zida nas demais casas agostinhas do reino. ${ }^{17}$ Embora as resistências internas da província portuguesa indicassem a existência de grupos em confronto, os reformadores neutralizaram naquele momento os adversários mais agressivos. $^{18}$ Tanto Montoia como Vilafranca, que recebeu ademais a distinção de ser confessor da rainha d. Catarina, integraram-se ao processo de reforma da ordem impelido por d. João III. Em carta de 16 de abril de 1539 ao novo geral da ordem, Girolamo Seripando, o monarca expressara o seu grande desejo de encontrar a "ordem reformada" e reforçara o seu papel na condução do processo de enquadramento. Girolano Seripando, geral da ordem por 12 anos (1539-1551), visitou a Província de Portugal seis anos após a chegada dos reformadores espanhóis, em 19 de julho de 1541, e foi recebido pelo monarca com honras de núncio. No périplo de visitação aos conventos portugueses por 40 dias, enalteceu os esforços de reforma conduzidos por Montoia e Vilafranca. ${ }^{19}$

Por sua vez, cabe atentar à reverberação das tendências pietistas na península Ibérica, com desdobramentos na ordem dos eremitas como um indicador da perduração do projeto de criação de uma recoleção agostinha, incitado por um dos seguidores de Luís de Montoia, frei Tomé de Jesus (1529c. 1582). Ressoavam na província portuguesa os reflexos das tensões de fraturas nas concepções de espiritualidade, nos costumes religiosos e sobre o papel da Igreja frente às dissensões produzidas pelas críticas do humanismo e às explosões protestantes no espaço europeu. É, entretanto, essencial acentuar os reflexos, nos espaços ibéricos, do erasmismo e do humanismo cristão de rompimento com a tradição, na crítica à escolástica e à frouxidão dos costumes eclesiásticos. E, por corolário, anima a ênfase na ascese, na espiritualidade de feição pietista, mais interiorizada, que tendeu a acentuar uma teologia de semblante místico. Os embates internos na ordem dos eremitas, frutos das consciências ibéricas do seu tempo, colocaram de sobreaviso o foro da Inquisição, advertência materializada no exemplo da condenação por luteranismo de frei Valentim da Luz em 1562. ${ }^{20}$

\footnotetext{
${ }_{17}$ DIAS, José Sebastião da Silva, 1975, op. cit., p. 17-20.

${ }^{18}$ Segundo Silva Dias, firmaram posição contrária à reforma, por um lado, os círculos adeptos da tradição e coniventes com os "frades relaxados" e, por outro, os ambiciosos pelo poder. Cabe atentar, ainda, para as influências de tendência pietista entre os eremitas que se aproximavam das concepções teológicas agostinianas de espiritualidade. DIAS, José Sebastião da Silva, 1960, op. cit., p. 120-129.

19 ALONSO, Carlos. La fundación del colegio agustiniano de $\mathrm{N}^{\text {tra }} \mathrm{S}^{\text {ra }}$ de Gracia de Coimbra (15431551). Revista da Universidade de Coimbra, vol. XXXVI, 1991a, p. 328.

${ }^{20}$ DIAS, José Sebastião da Silva, 1975, op. cit., p. 14.
} 
Não é o caso, neste artigo, de aprofundar as dissensões acerca dos sentidos doutrinários de espiritualidade e ascese, mas apenas registrar a densa trama que envolveu o campo religioso em Portugal, com implicações no jogo político e cuja influência se manifestou não somente nas gerações seguintes da ordem dos eremitas, como nos segmentos da sociedade europeia cristã, como é ilustrativa a ampla circulação dos escritos de frei Tomé de Jesus. Esse horizonte de espiritualidade traça a ambiência de experiências que unira vultos de proeminência agostinha no longo tempo da segunda metade do século XVI e das duas primeiras décadas do seguinte: Luís de Montoia, Agostinho de Jesus e Aleixo de Meneses. Como é notório, o projeto de fundação de um convento de uma recoleção com ênfase na oração e na austeridade foi suspenso, só se concretizando no século seguinte, após a restauração bragantina em 1664, com a criação do ramo dos agostinhos descalços da observância.

Devemos, porém, reter a relevância de Montoia no disciplinamento dos eremitas agostinianos em Portugal, prenunciando os futuros efeitos do Concílio de Trento. A sua trajetória comprova a presença em posições cimeiras na província portuguesa agostinha: reitor do colégio de Coimbra, prior do convento de Lisboa, cabeça da ordem portuguesa, vigário-geral da ordem em Portugal, preceptor do pequeno d. Sebastião e seu confessor, nomeado em 1566, função a que findou por renunciar. ${ }^{21}$

É cabível operar com uma referência que destaque a centralidade do reinado de d. João III no delineamento da construção tanto dos aparatos administrativos quanto da transformação das consciências na adesão a uma cosmovisão católica centrada no rei como cabeça do corpo místico. E ainda compreender como esse legado, no sentido de uma herança, perdurou e foi perpetuado na legitimação da hegemonia Habsburgo em Portugal, no período dos dois primeiros Filipe. No escopo imperial, cabe atentar para as disputas entre ordens religiosas pela proeminência na conquista de espaços do novo orbe cristão do ultramar e para o lugar dos eremitas de Santo Agostinho nos mundos ibéricos dos Áustria, seja na atuação na América espanhola, como também na sucessiva projeção no Estado da Índia ao final dos Quinhentos. ${ }^{22}$

\footnotetext{
${ }^{21}$ CRUZ, Maria do Rosário de Sampaio Themudo Barata de Azevedo. As regências na menoridade ded. Sebastião. Elementos para uma história estrutural, vol. 2. Lisboa: Imprensa Nacional-Casa da Moeda, 1992, p. 207.

22 Ângela Barreto Xavier atenta para a dimensão imperial do projeto monárquico de d. João III, bem como para a percepção do Estado da Índia enquanto Portugal no Oriente. Nessa perspectiva, a proeminência de um novo renascer do Império romano traz, na experiência do Oriente, a ideia de uma "refundação imperial". XAVIER, Ângela Barreto. A invenção de Goa.
} 
O que importa retermos, por ora, como a historiografia já tem assinalado, é a conexão entre as antigas relações clientelares da casa da rainha de Avis e os Áustria no período da monarquia dual. Portanto, frei Diogo de Santa Anna, na referência com a qual iniciamos este artigo, no encaixe das peças de uma memória familiar, amplifica o registro de seu pertencimento a um sistema de patronagem antigo. E, deste modo, dota seu nome de autoridade no contexto da defesa do mosteiro de monjas agostinhas na querela com o Senado da Câmara de Goa na década de 1630. Portanto, essa memória ainda fornecia sentido a um conjunto de símbolos de vínculos de lealdade e de relações pessoais cortesãs. A perspicaz lembrança remete à importância da ligação entre a ordem dos agostinhos e os poderes palacianos que selou a consolidação da Província de Portugal na segunda metade do século XVI, tanto no reino como no Estado da Índia.

Em suma, nos limites de nossa análise, é propedêutico sugerir que, a partir do reinado de d. João III, se delineia um quadro de fortalecimento da Província de Portugal dos agostinhos e de orbitação nos circuitos reais de $\mathrm{d}$. Catarina, prolongando-se pelo reinado de d. Sebastião, quando foi enviada a primeira missão dos agostinhos ao Estado da Índia. O processo de reforma da ordem dos eremitas, levado a cabo a partir do reinado de d. João III, facultou sua relevância na construção dos aparatos administrativos e da ação missionária no quadro de uma monarquia confessional católica afirmada na sequência dos desdobramentos da política religiosa do período pós tridentino nas "terras novas" no oriente do orbis christianus.

\section{D. frei Agostinho de Jesus e o arcebispado de Braga}

Do modelo trentino de bispo do pastor de almas, em que Bartolomeu dos Mártires constitui um ícone, a arquidiocese de Braga passaria a ser dirigida, entre 1588 e 1609, por um antístite que aliou o ideal pastoral ao de governo com o pragmatismo político, um perfil de bispo também acalentado pelo ambiente pós-tridentino. ${ }^{23}$ D. frei Agostinho de Jesus, Pedro de Castro de nome secular, recebeu o nome do avô por linha materna, $3^{\circ}$ conde de Monsanto, de conhecida ligação ao centro do poder monárquico, que ocupara a

Lisboa: ICS, 2008, p. 47, 57. Conduzo também à leitura do capítulo 1, intitulado "Reforma do reino, reforma do império".

${ }^{23}$ Acerca das acepções de bispo pastor e da dimensão política do perfil episcopal que predominaria no século XVII, baseei-me na reflexão de PAIVA, José Pedro, op. cit., p. 140-148. 
posição de vedor da fazenda nos reinados de d. Manuel I e de seu filho d. João III. ${ }^{24}$ Maria Ayala, sua mãe, fora uma das damas da rainha d. Catarina, e seu pai, d. Fernando de Castro, governador da casa do Cível de Lisboa. ${ }^{25}$ Aos 17 anos, Pedro de Castro recebeu o hábito dos eremitas de Santo Agostinho, vestido por frei Luís de Montoia, e adotou por nome religioso Agostinho de Jesus. Professou no instituto da ordem após dois anos, em 7 de abril de 1555.

As conexões de linhagem e a proximidade com Montoia deram início a uma carreira ascensional na ordem. Ocupou as posições de prior do convento de Villa Viçosa e de reitor do Colégio de Nossa Senhora da Graça de Coimbra. Foi provincial geral de Portugal por duas vezes: de 1570 a 1572 e de 1582 a 1584. No intervalo dos dois períodos, a pedido do imperador Rodolfo II (r. 1576-1611) do Sacro Império Romano, foi designado pelo papa Gregório XIII para definidor geral dos eremitas de Santo Agostinho na reforma da ordem na Germânia, ainda em época de esplendor da associação entre os Habsburgo de Áustria e Castela. A ligação próxima com a tia de d. Filipe II e mãe de Rodolfo II, a imperatriz d. Maria de Habsburgo, de quem foi confessor, formou mais uma das junções que favoreceram a bem-sucedida carreira nos meandros eclesiástico e político à época da monarquia dos Áustria. Em Espanha, conduziu ainda a reforma das províncias de Aragão e a separação da Província de Castela, com a criação da divisão da Andaluzia.

D. frei Agostinho de Jesus participou, em Roma, da elaboração das novas constituições de 1581, que adequaram a Ordem dos Eremitas de Santo Agostinho às determinações de Trento. ${ }^{26}$ No foco do impacto do luteranismo de origem agostiniana, o reordenamento da ordem vislumbrou-se nas edições das constituições de 1555 e 1581. Já a última tendeu a seguir as constituições da Companhia de Jesus de 1558. A redação foi organizada pelo então

\footnotetext{
${ }^{24}$ Ocupou o lugar de vedor da fazenda em 1501 no reinado de d. Manuel. A posição de vedor provinha do dote que recebera pelo casamento com d. Inês Ayala, filha de d. Diogo da Silva, $1^{\circ}$ conde de Porto Alegre. Permaneceu na posição de vedor até sua morte, em 1529. Cf. CRUZ, Maria Leonor Garcia da. A governação de d. João III: a fazenda real e os seus vedores. Lisboa: Centro de História da Universidade de Lisboa, 2001, p. 37, 39, 42.

${ }^{25}$ MACHADO, Diogo Barbosa. Biblioteca lusitana,historica, critica, e cronologia. Na qual se comprehende a noticia dos authores portugueses...., vol. I. Lisboa: Officina de Antonio Isidoro da Fonseca, 1741, p. 61, 62. Acerca de Agostinho de Jesus e Aleixo de Meneses, consulte-se: PAIVA, José Pedro, op. cit, p. 377-378; 380-381.

${ }^{26}$ As informações biográficas de Agostinho de Jesus constam em MACHADO, Diogo Barbosa, op. cit., p. 61-63; VELA, Gregório de Santiago. Ensayo de una biblioteca ibero-americana de la Orden de San Agustin, vol. I. Madri: Impr. del Asilo de Huérfanos del S. C. de Jesús, 1920, p. 656, 657 e LOPEZ, Teofilo Aparício, O.S.A., op. cit., p. 131-165.
} 
rev. hist. (São Paulo), n. 170, p. 107-141, jan.-jun., 2014 http://dx.doi.org/10.11606/issn.2316-9141.v0i170p107-141
Margareth de Almeida Gonçalves

A edificação da cristandade no Oriente português: questões em torno da Ordem dos Eremitas de Santo Agostinho no limiar do século XVII

geral da ordem, Tadeo Guindelli, que adequou o plano de escrita à legislação e aos decretos disciplinares tridentinos. ${ }^{27}$

Na posição de provincial da ordem dos eremitas agostinhos de Portugal, Agostinho de Jesus expediu, em 1572, a primeira missão dos agostinhos ao Estado da Índia. ${ }^{28}$ No mesmo ano, endereçou uma missão com 12 religiosos ao golfo da Guiné, na África ocidental. ${ }^{29}$ Este grupo dera continuidade à evangelização na ilha de São Tomé, iniciada em 1556 por frei Gaspar Cão. Havia aí uma forte alusão à simbologia sagrada do número, os 12 apóstolos de Cristo. Um sinal cifrado reapropriado pelas diversas ordens religiosas, como no exemplo das crônicas dos dominicanos portugueses, as quais registram, em 1548, o envio de 12 religiosos ao Estado da Índia. ${ }^{30}$ Portanto, são peças de um quebra-cabeça que indicam a definição de uma política de atuação dos agostinhos nos territórios do império, que operam com o imaginário do império cristão, e cuja gestação converge para d. frei Agostinho de Jesus. ${ }^{31}$

Em 1588, Agostinho de Jesus foi alçado ao posto de arcebispo de Braga e recebeu a consagração de primaz das Espanhas no ano seguinte. Por pedido de Filipe II, em procedimento usual ao monarca português, o papa Xisto V, pela bula Divina disponente clementia, de 13 de junho de 1588, confirmou o provimento no arcebispado de Braga. D. Francisco de Santa Maria, bispo de

\footnotetext{
${ }^{27}$ GUTIERREZ, vol. 2, 1971, op. cit. Em 1582, o capítulo provincial dos agostinhos de Portugal reconheceu e aprovou a nova constituição da ordem, promulgada em 1581 na cidade de Bolonha, que realizou a adequação da ordem aos parâmetros trentinos de disciplinamento, combinando uma maior intervenção nas ordens religiosas e o incentivo ao revigoramento do clero diocesano. Cf. Texto de las Actas Capitulares. Capítulo 1582. In: ALONSO, Carlos. Capítulos provinciales de la provincia de Portugal. Archivo Agustiniano, Valladolid, 196, 1994, p. 5-11.

${ }^{28}$ No capítulo provincial realizado no Convento de Santo Agostinho de Santarém, a 26 de outubro de 1571, conduzido pelo geral Agostinho de Jesus, foram assentadas as condições de instituição e fundação da ordem nas partes da Índia de Portugal. ALONSO, Carlos. Nueva documentación inédita sobre las misiones agustinianas en la India y en Persia (1571-1609). Analecta Augustiniana, Roma, 33, 1970, p. 311-313.

29 JESUS, d. frei Agostinho de. Regimento para os religiosos q foraõ para a Mina. AB/CC, documento $\mathrm{n}^{\circ}$. 1916. Já entre os agostinhos da primeira missão à Índia, constava frei Jorge Queimado, que retornou ao reino, e que foi então companheiro e confessor de d. frei Agostinho de Jesus e, em $1^{\circ}$ de fevereiro de 1599, foi confirmado como auxiliar e coadjutor de Braga pelo papa Clemente VIII, tendo recebido o título de bispo de Fez. Cf. ALONSO, Carlos. Nueva documentation inédita para una biografia de Agustín de Castro, O.S.A., arzobispo de Braga (1588-1609). Analecta Augustiniana, Roma, 53, 1991, p. 235; VELA, Gregório de Santiago. Ensayo de una biblioteca ibero-americana de la Orden de San Agustin, vol. VI. Madri: Impr. del Asilo de Huérfanos del S. C. de Jesús, 1920, p. 426. Acerca da missão do golfo da Guiné, consulte-se: ALONSO, Carlos. Os agostinhos em Portugal. Madri: Ediciones Religión y Cultura, 2003, p. 105, 106.

${ }^{30}$ ROLO, Raul A. Dominicanos. In: AZEVEDO, Carlos Moreira, op. cit., vol C-I, 2000, p. 86.

${ }^{31}$ LOPEZ, Teofilo Aparicio, O.S.A., op. cit., p. 136.
} 
Fez, tomou posse do arcebispado de Braga por procuração em nome de d. frei Agostinho de Jesus a 6 de novembro de 1588. Em todo o caso, em 3 de janeiro de 1589, após 34 anos do recebimento da profissão de religioso da ordem dos eremitas, o filho de Maria Ayala era sagrado arcebispo no Convento de Nossa Senhora da Graça de Lisboa pelo arcebispo de Lisboa, d. Miguel de Castro. Em 8 de março, fez a solene entrada na cidade de Braga, com o júbilo e as manifestações de pompa que caracterizavam as cerimônias de reconhecimento fundacional de novas autoridades episcopais.

A atuação de d. frei Agostinho de Jesus à frente do arcebispado seguiu os preceitos trentinos de disciplinamento social. Ao longo dos seus 21 anos de arcebispado, as alterações da rotina episcopal apontam para uma maior racionalização na administração.

Após 50 anos das constituições diocesanas providas pelo cardeal d. Henrique, quando arcebispo de Braga, redigiu novas. Para tanto, convocou o sínodo diocesano, que teve início a 11 de novembro de 1594 e, como lembrado, em dia da festa do santo fundador da cristandade ibérica, são Martinho. As constituições permaneceram, entretanto, no formato manuscrito. Uma revisão impressa foi editada ao final do século XVII, no ano de 1697, durante o período de prelatura de d. frei João de Sousa. Um segundo sínodo foi realizado em 18 de outubro de 1606, três anos antes do falecimento de Agostinho de Jesus, resultando na reforma dos costumes dos eclesiásticos e na moralização dos comportamentos de um clero percebido como distante do habitus do ofício de valorização da austeridade e das funções clericais. A relação tensa entre episcopado e cabido foi exposta em ocasiões diversas, conflito não unicamente bracarense, porém mais geral, em que a tendência de fortalecimento da autoridade arcebispal na uniformização da política católica tridentina agravara. Durante o arcebispado de Agostinho de Jesus, esse panorama de disputas das jurisdições do mando local sobre as extensões dos rebanhos emergiram em momentos vários, denunciando a resistência aos mecanismos de centralização ao poder mitral. Em 1590, quando foi criado o ofício do registro geral eclesiástico para o qual Agostinho de Jesus nomeou seu secretário particular, Sebastião d'Alfaro, recebeu forte oposição do cabido, o que ressalta o impacto dos conflitos jurisdicionais inerentes à esfera eclesiástica e a instabilidade da autoridade episcopal. ${ }^{32}$ A institucionalização

\footnotetext{
32 Sobre o período do arcebispado de Agostinho de Jesus na Sé de Braga, consulte-se: FERREIRA, monsenhor Augusto. Fastos episcopais da igreja primacial de Braga, tomo III. Braga: Edição Mitra Bracarense, 1928-1934, p. 72-95.
} 
do registro geral encontrou intenso ataque da mesa capitular, dirimido na elaboração final do seu regulamento a 4 de abril de 1591. Os mecanismos de arquivamento da documentação sedimentavam o delineamento de instrumentos de registro da rotina episcopal, como da fixação de coleções de documentos do passado da diocese primacial do reino. Foram reformados igualmente os estatutos do cabido, aprovados a 18 de outubro de 1600, uma versão de longa duração, adotada até o ano de 1949. A discordância às disposições dos estatutos assinala a reação a medidas que afetavam a autonomia capitular. A resistência à alteração do período de férias da corporação de cônegos de 100 para 90 dias, uma conformidade às orientações de Trento, demonstra a defesa pela manutenção de privilégios pretéritos.

No intento reformista, na proeminência da autoridade episcopal, Agostinho de Jesus acrescentou uma galeria de retratos dos bispos seus antecessores no paço episcopal e encomendou ao agostinho frei Jeronymo Román, cronista geral da Ordem dos Eremitas de Santo Agostinho em Espanha, a redação de uma História eclesiástica do arcebispado. As disputas pela memória contemplavam prerrogativas pretéritas. A irresoluta questão da primazia da diocese de Braga remontava aos tempos da reconquista e da formação do reino português com o reconhecimento pontifício de 1179 pela Manifestis probatum. A querela, que abrangia o direito de designação pelo metropolita de Braga do título de primaz das Espanhas, na rivalidade com Toledo, persistia à época de Agostinho de Jesus, apesar das tentativas de defesa da prerrogativa bracarense por Bartolomeu dos Mártires no Concílio de Trento. ${ }^{33}$ Um segundo aspecto das disputas sobre o passado fora a legitimidade da realização do rito bracarense. A procura de validação por provas documentais fundamentava a elaboração da história diocesana. O texto final de 1592 do confrade agostinho espanhol Jeronymo Román, La metropoli de Braga, permaneceu na versão manuscrita.

Por sua vez, Agostinho de Jesus manteve correspondência com o jesuíta de Toledo, frei Jerónimo Román de la Higuera (1538-1614), a quem se atribui os falsos Chronicões, um farto conjunto de documentação forjado pelo autor com circulação nos espaços ibéricos, responsável pela confirmação de ritos, cerimônias e mitos de fundação, como a lenda de Pedro de Rates como primeiro bispo de Braga. ${ }^{34}$

\footnotetext{
33 MARQUES, José. Braga. In: AZEVEDO, Carlos Moreira, vol. A-C, op. cit., p. 225-227.

${ }^{34}$ FERREIRA, monsenhor Augusto, op. cit., p. 76-78.
} 
No exercício da mitra, "aplicando-se ao pasto de suas ovelhas", ${ }^{35}$ seguiu mais uma das orientações do Concílio de Trento, que impelia o contato do clérigo com os fiéis. As visitas paroquiais confirmavam a adoção de instrumentos de controle e vigilância sobre as paróquias. Em geral, a adequação às determinações do Concílio de Trento foi repetida no reino pelos diversos bispados nas províncias eclesiásticas. Adensou-se um processo de reorganização burocrática, com a produção de textos normativos nos espaços ibéricos ao final do século XVI e no seguinte. Segundo Federico Palomo, a definição dos aparatos burocráticos de sustentação das instâncias episcopais foi constante no reino e tendeu a minimizar a relevância de poderes eclesiásticos, como os cabidos, fortemente presentes em períodos anteriores. ${ }^{36}$

O robustecimento da autoridade episcopal por Agostinho de Jesus remete ao processo mais amplo de ordenamento dos espaços eclesiásticos, em que os bispos ocuparam um lugar central de complemento do poder da Coroa, principalmente nas franjas do reino e no ultramar em que a extensa malha diocesana chegava. O peso do arcebispado português serviu de sustentação à afirmação da legitimidade filipina após o acordo de Tomar. ${ }^{37}$

Às tendências mais amplas de enquadramento eclesiástico, Agostinho de Jesus acrescentou uma bagagem de linhagem que somou experiência no exercício de ofícios nos centros de poder real e o uso de um capital nobiliárquico em benefício da casa. Uma acepção de casa alargada que engloba a de linhagem Noronha-Castro, e a espiritual, os eremitas de Santo Agostinho. Predomina uma lógica de governo da casa que assinala as duas décadas de permanência à frente da mitra bracarense. Demonstra habilidade e perspectiva política na defesa dos interesses da linhagem através da concessão de benefícios episcopais a familiares. Portanto, fez uso de um recurso corrente ao cargo mitrado entre as dignidades eclesiásticas. Por esta forma, em decreto arcebispal de 10 de abril de 1590, solicitava ao agostinho Egídio da Apresentação que conferisse o provimento da metade sine cura da igreja de Maria de Moreira, em terra de Monção, pertencente à administração de Valença do arcebispado de Braga e que vagara por falecimento do beneficiado, ao seu "sobrinho legítimo" d. Carlos de Meneses. ${ }^{38}$ Já em carta posterior ao

\footnotetext{
35 CUNHA, dom Rodrigo da. História eclesiástica dos arcebispos de Braga. Braga: Gráfica de Barbosa e Xavier, 1989, p. 406.

36 PALOMO, Federico, 2004, op. cit., p. 83, 84.

37 Idem, p. 62.

38 Conforme indicação que consta do Decreto Arzobispal..., de 10 abril 1590. Documento transcrito em ALONSO, Carlos. Documentación inédita sobre fr. Agustín de Jesús, O.S.A. arzobispo
} 
rev. hist. (São Paulo), n. 170, p. 107-141, jan.-jun., 2014 http://dx.doi.org/10.11606/issn.2316-9141.v0i170p107-141
Margareth de Almeida Gonçalves

A edificação da cristandade no Oriente português: questões em torno da Ordem dos Eremitas de Santo Agostinho no limiar do século XVII

papa Clemente VIII, de 28 de novembro de 1592, no latim pontificial, dirigiu um pedido em que solicitava contemplar, com o beneficium simplex da igreja de S. Cristovão de Mondim, seu parente d. Carlos de Noronha, filho de d. Antonio de Meneses e d. Joana de Castro. ${ }^{39}$ Sobre o falecimento do último possuidor, d. Pedro de Vasconcelos, acrescenta que fora parente consanguíneo do arcebispo anterior, d. João Afonso de Vasconcellos. E, a seguir, enumera as qualidades de seu protegido: "meu parente, adolescente de futuro promissor (da melhor expectativa - optimae spei), com 21 anos de idade, que, com o maior louvor e admiração de todos, se empenha, às minhas custas, em direito pontifício, na Academia de Coimbra, por já 4 anos". ${ }^{40}$

Do mesmo modo, a ocupação de funções cimeiras na hierarquia eclesiástica configura-se na sorte de prover benesses à família espiritual. Um decreto arcebispal de 16 de abril de 1590 garantiu a dotação sobre a arrecadação de esmolas nos dias santos e aos domingos à confraria de Nossa Senhora da Graça do convento agostinho de Lisboa. O decreto informava o montante que deveria ser entregue pelos párocos quando se deslocassem à Sé de Braga, ao buscarem os santos óleos, e recolhido pelo provisor ou vigário-geral. ${ }^{41}$ No ano seguinte, o regimento de 4 de maio oferecia instruções detalhadas acerca do emprego de dois mil cruzados arrecadados a favor do convento de Lisboa. Instruía que o montante deveria ser investido na aquisição de mercadorias para troca comercial na carreira da Índia:

No ano de 1589, demos de esmola ao mosteiro de N. Sra da Graça de Lixboa mil cruzados em dinheiro, para o muito reverendo padre provincial e o reverendo padre prior do dito mosteiro os mandassem nas naos que em o mes de março do ditto ano partiram para a India Oriental, empregados em mercadorias que lá tem valia, ou em reales castelhanos, para de la da India, por correspondencia dos Padres da mesma Ordem que lá estão

de Braga (1588-1609). Analecta Augustiniana, Roma, 34, 1971, p. 119, 120. Segundo Hespanha, “o benefício é um direito perpétuo, atribuído por uma autoridade eclesiástica, de receber frutos de certos bens da Igreja, em virtude de um ministério (ou ofício) sagrado, ao qual foram consignados ou anexados". Apud HESPANHA, António Manuel. Os bens eclesiásticos na época moderna. Benefícios, padroados e comendas. In: TENGARRINHA, José (org.). História de Portugal. Bauru, SP: Edusc; São Paulo: Unesp, 2000, p. 87-104.

${ }^{39}$ D. Joana, por sua vez, era filha do irmão mais velho de d. frei Agostinho de Jesus, d. Jerônimo de Castro.

${ }^{40} \mathrm{Na}$ transcrição do original em latim, veja-se: "meo agnato, optimae spei adolescenti, unum et viginti annos nato, qui summa cum laude et admiratione omnium in Academia Conimbricensi iam a quatuor annis iuri pontificio meis expensis oepram navat". Veja-se ALONSO, Carlos. De fr. Agustin de Jesús a Clemente VIII: Pide para su pariente d. Carlos de Noronha un beneficio simple de la iglesia de S. Cristóbal de Mondim. Analecta Augustiniana, Roma, 34, op. cit., p. 128, 129.

${ }^{41}$ Decreto Arzobispal..., de 16 abril 1590, ibidem, p. 120, 121. 
tornarem a vir nas mesmas naos os dittos mil cruzados e ganhos deles empregados em mercadorias de lá que cá em Portugal mais valem. ${ }^{42}$

Trata-se de uma peça pedagógica sobre como aplicar o dinheiro das esmolas para prover ganhos que multipliquem a quantia e garantam proventos do investimento, os quais reverteriam aos fundos da ordem no reino. O regimento indica habilidades de contabilidade em que a tradição dos Noronhas na vedoria da fazenda é replicada, como também demonstra um uso legítimo de noções morais do ganho justo em atividades de comércio no engrandecimento material e espiritual da ordem religiosa. A ponte agostinha entre o reino e a Índia possibilitou a combinação de negócios da empresa da cristandade e o trato mercantil.

A conexão entre Braga e Goa fora robustecida, em mais uma iniciativa do antístite, na fundação do Colégio do Pópulo dos eremitas de Santo Agostinho em Braga em 1596, assentando um arrimo na formação de vocações religiosas ao clero diocesano, como também aos espaços do Estado da Índia, já no início do arcebispado de Aleixo de Meneses. Na diligência de fortalecimento de uma malha pedagógica de vocações missionárias agostinhas, fundou-se, seis anos após, em 1602, o Colégio do Pópulo, contínuo ao convento dos gracianos, em Goa.

Entretanto, duas décadas antes, em 1572, Agostinho de Jesus, ainda quando superior da Província de Portugal, enviou ao Estado da Índia a primeira missão de religiosos, como assinalado acima, o começo da Congregação da Índia Oriental, subordinada à província de Portugal. Desde a primeira missão, os eremitas de Santo Agostinho ocuparam posições na região do mar arábico. A crônica de frei Simão da Graça (c. 1669) recuperou o papel de Agostinho de Jesus nas missões do Estado da Índia: "o qual inspirado por Deos nosso senhor achou convinha de estender-se, edificasse nossa sagrada religião pelas partes orientais".43

A fundação, em 1572, de uma casa de religiosos agostinhos em Ormuz recebeu a aprovação do monarca d. Sebastião, com o fito de procederem ao

\footnotetext{
${ }^{42}$ Regimento que se ha de guardar no emprego dos dois mil cruzados de que nos, dom frei Agostinho de Jesu, arcebispo primas, fizemos esmola ao mosteiro de Nossa Senhora da Graça de Lisboa da ordem de nosso glorioso... e do que se ha de fazer dos ganhos deles, 4 de maio de 1591. AB/CC, n. 2091. A transcrição encontra-se em ibidem, p. 123, 124.

${ }^{43}$ GRAÇA, frei Simão da. Da origem, extensão e propagação da religião dos Eremitas de N. P. Santo Agostinho pelas terras destas partes orientais. Livro segundo, fl. 1. ANTT/ML, n 1699 (microfilme $\mathrm{n}^{\circ}$. 2749).
} 
rev. hist. (São Paulo), n. 170, p. 107-141, jan.-jun., 2014 http://dx.doi.org/10.11606/issn.2316-9141.v0i170p107-141
Margareth de Almeida Gonçalves

A edificaç̃ão da cristandade no Oriente português: questões em torno da Ordem dos Eremitas de Santo Agostinho no limiar do século XVII

"negócio de conversão dos gentios". ${ }^{4}$ Para tanto, o futuro convento recebeu a designação comum aos agostinhos portugueses de Nossa Senhora da Graça. ${ }^{45}$ A presença de religiosos no Índico ocidental coadunou-se ao projeto de renovação administrativa do Estado da Índia tentado no reinado de d. Sebastião. O motivo da divisão do Império oriental, segundo o cronista Diogo de Couto, foi a dispersão dos espaços portugueses. Procedeu-se à separação em três governos: a área que se estende do mar Arábico até o Ceilão, controlada pelo vice-rei d. Antonio de Noronha; a África oriental entregue ao governador Francisco Barreto e o Índico oriental ao governador Antonio Moniz Barreto. ${ }^{46}$ Porém, o projeto não progrediu; minara em um reino "desventurado" pela morte do soberano. ${ }^{47}$

A rede de conventos agostinhos consolidou-se no Estado da Índia predominantemente no período entre 1572 e 1606, com o impulso de d. frei Agostinho de Jesus - quando provincial em Portugal e, depois, quando já no arcebispado de Braga - e de d. frei Aleixo de Meneses, na sede primaz de Goa a partir de 1595. Com o intuito de "dilatação da fé", a Congregação do Oriente espalhou casas no Índico ocidental, em Mombaça, na costa suaíli da África oriental, nas regiões da Pérsia, nas áreas designadas por províncias do norte (Tana e Chaul), em Goa, Cochim, na costa do Malabar, e no Ceilão. Na parte leste do Índico, avançaram por São Tomé de Meliapor, Ugulim (Bengala), Malaca e Macau (figura 1). ${ }^{48}$ Formou-se uma extensa malha que alastrou os agostinhos do litoral da África oriental ao mar da China meridional.

\footnotetext{
${ }^{44}$ Alvará de 18 de fevereiro de 1576. In: RIVARA, J. H. da Cunha. Archivo Portuguez Oriental. Fascículo 6, Suplementos primeiro \& segundo. Nova Deli/Madras: Asian Educational Services, 1992, p. 713.

${ }^{45}$ ALONSO, Carlos. Nueva documentación inédita sobre las misiones agustinianas en la India y en Persia (1571-1609). Analecta Augustiniana, Valladolid, 33, 1970, p. 312, 314.

${ }^{46}$ COUTO, Diogo de. Da Ásia. Década nona. Lisboa: Na Regia Officina Typografica, 1786, p. 1. Sanjay Subrahmanyam menciona as reformas administrativas do reinado de d. Sebastião e assinala a passagem de uma "vocação marítima" do Império para uma progressiva ênfase territorial. Cf. SUBRAHMANYAM, Sanjay. O Império asiático português, 1500-1700. Uma história política e econômica. Lisboa: Difel, 1995, p. 172.

${ }^{47}$ Essa é uma alusão à expressão "desventurados reinos os dos reis crianças" em: SOUSA, Manuel de Faria. Asia portuguesa, vol. IV. Porto: Livraria Civilização, 1946, p. 134.

${ }^{48}$ Atente-se à sequência cronológica de fixação dos agostinhos: Goa (1572); Ormuz (1573); Taná (1574); Cochim (1580); Chaul (1587); Macau (1587); Malaca (1590); Mascate (1595); Baçaim (1595); Mombaça (1597); Damão (1599); Ugulim (1599); Ispahan (1602); São Tomé de Meliapor (1603); Colombo (1606). É procedente reparar para a distribuição de religiosos entre as casas, que, à exceção do convento cimeiro da ordem em Goa, contavam provavelmente com não mais que quatro ou cinco membros. Na montagem do mapa, recorremos principalmente a dois cronistas da Congregação da Índia Oriental - na medida do possível, essas informações foram confrontadas com outras fontes documentais: frei Simão da Graça (c. 1669) e frei Manuel de
} 
Cabe reforçarmos a reflexão acerca das conexões entre os agostinhos e os Habsburgo, facilitando um enraizamento nos espaços de novas cristandades. Vale lembrar, a propósito, que o início da ação missionária dos agostinhos espanhóis nas Filipinas sucedeu-se a partir de 1565, através de Nova Espanha, sete anos antes dos agostinhos da Província de Portugal chegarem aos espaços asiáticos. Embarcaram na frota liderada por Miguel López de Legazpi, futuro governador das Filipinas, que exitosamente estabeleceu o domínio Habsburgo nas ilhas do Pacífico. Foram religiosos agostinhos que acompanharam a expedição que finalmente ligou a extremidade leste da Ásia e a costa americana da Nova Espanha, numa nova geografia do império de Filipe II, estreitando rotas comerciais no escoamento da prata de Potosí ao Império Ming e de mercadorias chinesas às regiões da América espanhola. ${ }^{49}$

\section{D. frei Aleixo de Meneses e o arcebispado de Goa}

O agostinho d. frei Aleixo de Meneses, entretanto, seguiu a rota tradicional dos navegantes portugueses, pelo eixo do Atlântico e do Índico ocidental. Partiu em 13 de abril de 1595. Como era comum, o novo metropolita atravessou um longo percurso marítimo, pontuado por doenças a bordo, em que, segundo uma carta a Agostinho de Jesus, teve de "começar a ser Bispo e a curar as minhas ovelhas". Chegaram à cidade metrópole do Estado da Índia em 29 de setembro do mesmo ano. ${ }^{50}$

A trajetória de d. frei Aleixo de Meneses no Estado da Índia ocasionou a solidificação do projeto, germinado no reinado de d. Sebastião, de construção da missionação agostinha, quando Agostinho de Jesus foi geral da Província de Portugal. Da mesma forma que o "pai espiritual", d. frei Aleixo de Meneses exibe relações parentais de vínculos com o reinado de d. João

\footnotetext{
Ave Maria (1817). Cf. GRAÇA, frei Simão da, op. cit., fls. 3, 4; AVE MARIA, Manuel de. Manual Eremítico da Congregação da Î́ndia Oriental dos Eremitas de N. P. S. Agostinho. In: REGO. António da Silva. Documentação para a história das missões do padroado português do Oriente. Índia, vol. XI. Lisboa: Fundação Oriente/Comissão Nacional para as Comemorações dos Descobrimentos Portugueses, 1996, p. 103-221. Agradeço a confecção do mapa ao estudante Eduardo Pereira do curso de graduação em geografia do IM/UFRRJ.

${ }^{49}$ RUBIAL GARCÍA, Antonio. Uma monarquia criolla. México: Direción Geral de Publicaciones del Cons. Nac. para La Cultura y las Artes, 1990.

${ }^{50}$ Vejam-se, também, sobre o arcebispado de Aleixo de Meneses em Goa, os seguintes estudos: PINTO, Carla Alferes, op. cit.; GOMES, João M. D. Frei Aleixo de Meneses. Goa-Braga: Trajecto de uma missão. Theologica, II série, vol. XLI, fac. 2, 2006, p. 370-371.
} 
III e o círculo da rainha d. Catarina. Essas conexões conduziram ambos à conquista de posições de relevo durante a monarquia dual.

D. frei Aleixo de Meneses, nome secular de Pedro de Meneses, pertencera igualmente à casa de primeira nobreza do reino. D. Aleixo de Meneses ( $†$ c. 1569), seu pai, era o terceiro filho do segundo casamento de Pedro de Meneses, $1^{\circ}$ conde de Castanhede, com d. Beatriz de Soares, viúva do marechal d. Álvaro Coutinho. D. Aleixo foi mordomo-mor da rainha d. Catarina, entre 1554 e 1559, e aio de d. Sebastião em 1559. Porém, antes da fixação em ofícios cortesãos no reino, fez carreira no norte da África e na Índia, o que favoreceu uma combinação de fama e notoriedade nos espaços reais de d. João III.

$\mathrm{O}$ aio de d. Sebastião foi um dos membros de grupo senhorial que firmou posições de poder na monarquia Avis no século XV. ${ }^{51} \mathrm{O}$ percurso da linhagem teve, na expansão no ultramar, a oportunidade de ascenso a lugares próximos ao centro político. Ao desempenho inicial no norte da África sucedeu a atuação nas partes asiáticas. Com o irmão d. Gaspar de Meneses, integrou a armada liderada por d. Jaime de Bragança, duque de Bragança, a Azamor em 1513. Cinco anos mais tarde, em 1517, acompanhou os governadores da Índia portuguesa, Lopo Soares de Albergaria (1412-1520), seu tio, irmão de sua mãe, e Diogo Lopes Sequeira (1465-1530), período em que adicionou prestígio por serviços à monarquia que o alçaram a postos no reinado do Piedoso. ${ }^{52}$ Já no reino, em 1542, conduziu a embaixada ao imperador Carlos V, irmão de d. Catarina, e dirigiu as negociações do casamento da princesa d. Maria e do seu primo, príncipe d. Filipe, futuro Filipe II. Na função de mordomo-mor da princesa e na proximidade com o príncipe, foi padrinho do filho do casal, príncipe d. Carlos - futuro personagem do drama amoroso de filho e pai por Isabel de Valois (terceira esposa de Filipe II), eternizado pela ópera de Verdi. Portanto, Filipe II, ao nomear o filho de

\footnotetext{
${ }^{51}$ A produção historiográfica sobre os Meneses é conhecida. Reencaminho, a seguir, a alguns estudos de formato prosopográfico que acentuam a relação entre os Meneses e o poder real: LACERDA, Teresa. Os Meneses de Castanhede e o projecto manuelino. In: COSTA, João Paulo Oliveira; RODRIGUES, Vítor Luís Gaspar. A alta nobreza e a fundação do Estado da Índia. COLÓQUIO INTERNACIONAL. Actas. Lisboa: Cham/IICT/Univers. Nova de Lisboa, 2004, p. 75-93; CARVALHO, Cátia; FURTADO, Marta; URBANO, Pedro; VALENTE, Tiago. Os Meneses de Castanhede na construção política do império de d. João III. D. JO ÃO III E O IMPÉRIO. CONGRESSO INTERNACIONAL COMEMORATIVO DO SEU NASCIMENTO. Actas. Lisboa : CHAM/ Cepcep, 2004, p. 295-306.

${ }^{52}$ Veja-se: VASCONCELOS, António Maria Falcão Pestana de. Nobreza e ordens militares. Relações sociais e de poder (séculos XIV a XVI), vol. 2. Dissertação de doutorado em História Medieval e do Renascimento, Faculdade de Letras/Universidade do Porto, 2008, p. 217.
} 
d. Aleixo de Meneses para ocupar a Sé vacante de Goa, levara em conta um antigo vínculo familiar de relações cortesãs.

O amplo verbete sobre d. Aleixo de Meneses na Biblioteca lusitana, de Diogo Barbosa Machado, é eivado de elogios: "foi valoroso capitão, prudente embaixador, consumado político, e em tão diversos ministérios preferiu a honra ao interesse, a benevolência à severidade, e a verdade à lisonja". ${ }^{53}$ Esse é mais um dos exemplos que indicam a articulação entre a expansão e a atuação no Índico com a ocupação de posições administrativas e palatinas, como já assinalado por Mafalda Soares da Cunha e Nuno Monteiro. ${ }^{54}$ Em d. Aleixo de Meneses, desponta o perfil modelar das qualidades de fidalguia que aliavam o artifício da humildade desinteressada cristã à honra do nobre, traços reproduzidos na trajetória de seu filho na carreira religiosa cortesã.

Por sua vez, a mãe de d. frei Aleixo de Meneses, d. Luiza de Noronha, era filha de d. Álvaro de Noronha, que fora capitão de Azamor. Filho do segundo casamento de d. Aleixo de Meneses, ${ }^{55}$ Pedro de Meneses nasceu em 25 de janeiro de 1559, na cidade de Lisboa. ${ }^{56}$ Professou no convento da Graça na capital do reino e recebeu-o d. frei Agostinho de Jesus, em 27 de fevereiro de 1575. Na nova identidade religiosa, mudou o nome para Aleixo de Jesus, apesar de manter a opção pelo apelido Meneses. Passou pela Universidade de Coimbra, entre 1582 e 1586, como demonstram as listas de capítulos provinciais dos agostinhos de Portugal, primeiro por estudante corista e depois já na posição de sacerdote. Contudo, não chegou a finalizar os estudos acadêmicos. ${ }^{57}$ Na Província de Portugal dos agostinhos, foi eleito prior dos conventos de Torres Vedras, em 1588, de Santarém, em 1590, e de Lisboa, em 1592.

\footnotetext{
${ }_{53}$ MACHADO, Diogo Barbosa, op. cit., vol. I, p. 88, 89.

${ }^{54}$ CUNHA, Mafalda Soares da; MONTEIRO, Nuno Gonçalo. Vice-reis e governadores da Índia: uma abordagem prosopográfica (1505-1834). In: Encontro sobre Portugal e a Índia. Lisboa: Livros Horizonte/Fundação Oriente, 2000, [175-185], p. 175, 176. Consulte-se também: CUNHA, Mafalda Soares da. A Casa de Bragança e a expansão, séculos XV-XVII. In: COSTA, João Paulo Oliveira; RODRIGUES, Vítor Luís Gaspar, op. cit., p. 304, 305.

${ }^{55}$ Diogo Barbosa Machado afirma que d. Aleixo de Meneses contava 71 anos quando do segundo casamento e que, no enlace, tivera cinco filhos com d. Luiza da Silveira. Cf. MACHADO, Diogo Barbosa, op. cit., vol. I, p. 86.

${ }^{56}$ Idem, p. 88. Acerca de frei Aleixo de Meneses, veja-se: ALONSO, Carlos. Alejo de Meneses, O.S.A. Arcebispo de Goa (1595-1612). Valladolid: Ed. Estudio Agustiniano, 1992, especialmente p. 18-28. Consultem-se também SUBRAHMANYAM, Sanjay, 1998, op. cit., p. 21-42; PAIVA, José Pedro, op. cit., p. 278 e OLIVAL, Fernanda. D. Filipe II. Lisboa: Círculo dos Leitores, 2006, p. 163, 164.

57 ALONSO, Carlos. Alejo de Meneses, O.S.A..., op. cit., p. 17, 18.
} 
rev. hist. (São Paulo), n. 170, p. 107-141, jan.-jun., 2014 http://dx.doi.org/10.11606/issn.2316-9141.v0i170p107-141
Margareth de Almeida Gonçalves

A edificaç̃ão da cristandade no Oriente português: questões em torno da Ordem dos Eremitas de Santo Agostinho no limiar do século XVII

No processo de condução de Aleixo de Meneses à mitra de Goa, foi elevado ao lugar de pregador real de Filipe II, distinção que supriu a ausência da formação formal em teologia, como destacado nas provas reunidas ao processo consistorial de sua nomeação em Roma: "e embora não tenha nenhuma graduação em Direito Canônico, é insigne em Teologia Sagrada, é um grande teólogo e aplicou-se em letras sacras na Universidade de Coimbra, além de ser insigne pregador. Foi eleito e elevado entre os oradores, pelo rei".58

Antes da partida para Goa, foi expedido um breve pela chancelaria papalina de Clemente VIII, que concedeu faculdades ministeriais a frei Aleixo de Meneses de absolver os religiosos agostinianos da Índia de qualquer pena de excomunhão, se porventura os dominicanos declarassem algum decreto contra eles. ${ }^{59}$ Os frades da ordem dos pregadores de Portugal usufruíam, em solenidades públicas e procissões de uma antiga posse de precedência aos eremitas de Santo Agostinho, aos religiosos de Nossa Senhora do Monte do Carmo e da Santíssima Trindade, na capela do Sumo Pontífice, em Roma, e nos limites da cristandade. ${ }^{60}$ Ademais, entre os termos de praxe do juramento de fidelidade prestado quando da consagração episcopal, Aleixo de Meneses comprometeu-se a perseguir e impugnar hereges, cismáticos e rebeldes. A construção da monarquia católica universal, projeto acalentado por Roma, encontrou no arcebispo goês um bastião, que aliou à política religiosa um "gosto" pela "conversão do infiel". A experiência do Estado da Índia projetara um universo de "ovelhas de várias cores" que o agostinho, um pastor de almas, comprometera-se a conduzir à obediência ao papa na Ecclesia romana. Entretanto, não obteve legado apostólico ou a condição de núncio, apesar de pedidos do rei católico. Por fim, pelo breve In specula summi apostolatus, de 22 de fevereiro de 1607, ${ }^{61}$ o papa Paulo V, embora não concedesse legado de representação papal, permitiu faculdades diversas, entre as quais as de autorizar a dispensa nos graus proibidos para contrair matrimô-

\footnotetext{
58 "Et licet non ist aliquo gradu in Iure Canonico vel in sacra Theologia insignitus, est tamen magnus theologus et Sacris Litteris operam dedit in Universitate studii generalis Colimbricensis et est insignis concionator et a rege inter regios concionatores electus et assumptus..." A transcrição do documento em latim foi publicada por ALONSO, Carlos. Sumario del proceso consistorial de fr. Alejo de Meneses. In: Documentación inédita para uma biografia de Meneses. Analecta Augustiniana, Roma, 27, 1964, p. 267.

59 Breve Venerabili Fratri archiepiscopo Goano seu dilecto filio eius officiali Clemens Papa VIII. In: ALONSO, Carlos, idem, op. cit., 1964, p. 271.

${ }^{60}$ CACEGAS, Luis O.P.; SOUSA, Luis O.P. Terceira parte da história de S. Domingos particular do reino e conquistas de Portugal, vol. IV. 3. ed. Lisboa, 6 vols., 1866, p. 497.

61 ALONSO, Carlos. Faculdades ministeriales en favor de Alejo de Meneses. Archivo Augustiniano, Valladolid, 71, 1987, p. 89-91.
} 
nio, com a justificativa da distância e da vastidão das regiões atendidas na Índia oriental. Um segundo breve, no mês seguinte, em 6 de março, ${ }^{62}$ acatou a realização do sínodo provincial a cada dez anos e não na prática instituída que seguia o intervalo de cinco anos, o que contemplou uma das súplicas do arcebispo de Goa, que se justificava por causa da distância dos sufragâneos, dificuldades de navegação, ou pelos incômodos que sofriam aquelas "tenras ovelhas por causa de tão contínuas e longas ausências de seus pastores".63

Apesar dos percalços com Roma - em época que sinalizava mudanças quanto à política missionária de Roma e o embate com o padroado ibérico -, d. frei Aleixo de Meneses construiu uma trajetória única e fulgurante na carreira eclesiástica e administrativa no âmbito da monarquia dos Áustria: arcebispo de Goa (1595-1610), a partir de 1606, acrescentou o título de primaz do Oriente, acumulou a função de governador do Estado da Índia; ${ }^{64}$ no retorno ao reino, exerceu a mitra no arcebispado de Braga (1612) em substituição ao pai espiritual d. frei Agostinho de Jesus e, nos últimos anos de vida, foi vice-rei de Portugal e presidente do Conselho de Portugal.

Os vínculos entre as famílias de d. frei Agostinho de Jesus e de d. frei Aleixo de Meneses com o Estado da Índia são conhecidos, como assinala Sanjay Subrahmanyam. ${ }^{65}$ A proximidade entre os Noronha e os Meneses por alianças matrimoniais expõe a intricada rede de casamentos e enuncia possibilidades variadas de vínculos parentais. ${ }^{66}$ Uma breve exploração genealógica indica conexões de linhagem que explicam, em notas biográficas, a alusão de um vínculo familiar, através do emprego do termo "sobrinho" atribuído a Aleixo de Meneses com relação a Agostinho de Jesus. Embora não se confirme o parentesco em linha direta, os ramos maternos dos insignes me-

\footnotetext{
${ }^{62}$ Idem, p. 92, 93. Veja-se, também: ALONSO, Carlos. Alejo de Meneses, O.S.A. ..., op. cit., p. 230, 231.

${ }^{63}$ No original, em latim, corresponde a "tenerae illae oves ex tam continua et prolixa suorum pastorum absentia", segundo transcrição em Memorial del agente de Portugal en Roma, en nombre del rey católico.... In: ALONSO, Carlos. Analecta Augustiniana, Roma, 27, op. cit., p. 297.

${ }^{64}$ Foi governador do Estado da Índia em duas ocasiões. A primeira, em 1600, durante a viagem do vice-rei Aires de Saldanha às províncias do norte e, novamente, no período de 1606 a 1609 , na ausência de d. Martim Afonso de Castro - no deslocamento às "partes do sul" para a defesa de Malaca dos ataques holandeses, seguindo-se sua morte em junho de 1607 -, quando, em 1609, o governador interino André Furtado de Mendonça ocupou o cargo até a chegada do novo vice-rei Rui Lourenço de Távora em 1610. Cf. ALONSO, Carlos. Alejo de Meneses. O.S.A...., op. cit., p. 242-244.

${ }^{65}$ Cf. SUBRAHMANYAM, Sanjay, 1998, op. cit., p. 31.

${ }^{66}$ LACERDA, Teresa. Os Meneses de Cantanhede e o projecto Manuelino. In: COSTA, João Paulo Oliveira; RODRIGUES, Vítor Luís Gaspar, op. cit., p. 75-93.
} 
rev. hist. (São Paulo), n. 170, p. 107-141, jan.-jun., 2014 http://dx.doi.org/10.11606/issn.2316-9141.v0i170p107-141
Margareth de Almeida Gonçalves

A edificaç̃ão da cristandade no Oriente português: questões em torno da Ordem dos Eremitas de Santo Agostinho no limiar do século XVII

tropolitas, por exemplo, remetem a um núcleo comum Noronha, de d. Afonso (1350-1395), conde de Gijón, e Noronha, filho bastardo do rei de Castela, d. Henrique, e de d. Isabel de Portugal (1364-1435), filha natural de d. Fernando I.

Dois agostinhos ocuparam simultaneamente arcebispados centrais durante a monarquia dos Áustria. Uma combinação de acaso e virtude que consolidou o enraizamento da Ordem dos Eremitas de Santo Agostinho no Estado da Índia. O longo período de duração do arcebispado de Aleixo de Meneses acentuou a expansão e o fortalecimento dos agostinhos nos espaços do subcontinente indiano, na região denominada de províncias do norte, no Gujarate e Bengala, assim como na Pérsia, em áreas de presença de comunidades portuguesas fora da colonização formal do Estado da Índia. Durante o período de seu arcebispado, os agostinhos do Estado da Índia conduziram um movimento para o interior, deslocando-se das partes litorâneas. Tal configuração sinaliza o desenho da geografia religiosa anunciada por Trento, com ênfase na ampliação da malha diocesana nos territórios submetidos às jurisdições das monarquias ibéricas, e o deslocamento do clero regular para as missões de alargamento das fronteiras da cristandade.

No diapasão trentino, o célere metropolita conduziu visitas pastorais; promoveu o Sínodo de Diamper (1599) de romanização dos cristãos sírios de São Tomé do Kérala, na costa do Malabar; realizou o $5^{\circ}$ Concílio Provincial de Goa em 1606, que teve por objetivo equacionar questões relativas ao governo eclesiástico no sentido de estreitar o controle sobre as práticas religiosas dos fiéis, com o alvo direcionado para o que se associava ao gentilismo.

No período em que permaneceu na mitra goesa, Aleixo de Meneses deu cumprimento às orientações do Concílio de Trento de disciplinamento das ordens regulares e de expansão da rede diocesana. ${ }^{67} \mathrm{O}$ pároco local adquiriu progressivamente, nos dois séculos após Trento, uma posição privilegiada entre o centro (rei, papa) e a periferia das conquistas (paróquias e fiéis). ${ }^{68}$ Ademais, a época de seu arcebispado assinalou o incentivo à ocupação de cargos diocesanos pelo clero de origem indiana. Ines Županov salienta que

\footnotetext{
${ }^{67}$ Segundo a crônica do agostinho nascido em Goa, frei Faustino da Graça († 1744), foram criadas 113 paróquias, das quais 40 em Goa, nos 15 anos em que durou o arcebispado de Aleixo de Meneses. Cf. GRAÇA, frei Faustino. Campos do ermo dos filhos de Sto Augustinho da Congregação da India oriental, plantado, regado, e brotado, dedicado... (1713), fl. 222. BPADE, CXVI/1-15. Esse cômputo de paróquias não difere significativamente das 116 igrejas paroquiais apontadas em SALDANHA, Manoel José Gabriel. História de Goa (Política e arqueologia). Nova Goa: Livraria Coelho, 1925, p. 364.

${ }^{68}$ PALOMO, Federico, 1997, op. cit., p. 125.
} 
o arcebispo agostinho foi receptivo às práticas do jesuíta italiano Roberto Nobili de adaptação do cristianismo ao hinduísmo no Madurai, embora isso tenha provocado fortes reações na hierarquia eclesiástica. ${ }^{69}$

A dimensão política do perfil de Aleixo de Meneses já foi de forma arguta estudada por Sanjay Subrahmanyam que mostra como sobressai a sua ação no complexo xadrez de disputas entre as esferas dos poderes religioso e temporal. No confronto com a dimensão do vice-reino, d. frei Aleixo de Meneses fez críticas a Matias de Albuquerque e ao $4^{\circ}$ conde da Vidigueira, d. Francisco da Gama, quadro que assinala a trama intricada das estruturas de poder no Estado da Índia ao alvorecer do século XVII. ${ }^{70}$ No entanto, Matias de Albuquerque, numa carta a d. Filipe II, tecera elogios ao arcebispo - "bom modo" com que conduz a "obrigação pastoral" -, despertando contentamento ao rei pelo serviço a Deus e à monarquia. ${ }^{71}$ Por sua vez, o antigo pajem de companhia de d. Sebastião, d. Álvaro de Meneses, irmão de d. frei Aleixo de Meneses, era casado com a irmã do conde da Vidigueira, d. Violante de Távora. O ambiente de tensões entre jurisdições expõe as disputas entre fidalgos, que eram endêmicas ao Estado da Índia e à própria monarquia, o que, em todo caso, demonstra a diversidade dos interesses em disputa. ${ }^{72}$

A boa acolhida com que recebeu o vice-rei d. Martim Afonso de Castro (1605-1607), filho do $4^{\circ}$ conde de Monsanto, d. Antonio de Castro, e primo de d. frei Agostinho de Jesus, ${ }^{73}$ constitui mais um elemento das estratégias no âmbito eclesiástico de fortalecimento das conexões familiares e clientelares no jogo político de defesa de posições e alianças, em que predomina uma combinação dos interesses privados da casa nobiliárquica e da ordem religiosa. O novo vice-rei, embora cravejado de elogios por Aleixo de Meneses, chegara à barra de Goa a 19 de maio de 1605 sem experiência administrativa e militar de relevo. Uma fragilidade do "soberbo" vice-rei, adjetivo atribuído por Manuel de Faria e Sousa, a que se somou o desastre na derrota para os holandeses da armada que comandou na defesa de Malaca. Embora o

\footnotetext{
69 ŽUPANOV, Ines G. O Império oriental, 1458-1665. A religião e as religiões. Tradução de Margarida Vale de Gato, p. 26. <http://www.ineszupanov.com/publications/HIST\%D3RIA\%20DA\%20 EXPANS\%C3O\%20PORTUGUESA\%202001.pdf acesso em 24/07/2011>.

${ }^{70}$ Veja-se SUBRAHMANYAM, Sanjay, 1998, op. cit., p. 34.

${ }^{71}$ Citação do alvará de 8 de janeiro de 1598, cf. RIVARA, J. H. da Cunha, op. cit., fascículo 3, p. 802.

${ }^{72}$ Em relação a d. Francisco da Gama, $4^{\circ}$ conde da Vidigueira, vejam-se, de SUBRAHMANYAM, Sanjay. O império asiático português, 1500-1700. Uma história política e econômica. Lisboa: Difel, 1993, p. 330, 331; Idem. Portugueses, mongóis, e a política do Decão, c. 1600. In: Ibidem. Impérios em concorrência. Histórias conetadas nos séculos XVI e XVII. Lisboa: ICS, 2012, 233-241.

73 ALONSO, Carlos. Alejo de Meneses. O.S.A...., op. cit., p. 240, 241.
} 
domínio português da importante base malaia do comércio asiático fosse mantido por pouco mais de três décadas, os efeitos do confronto fincaram irremediavelmente o poder holandês nos mares do Oriente.

Entretanto, a morte por enfermidade de d. Martim Afonso de Castro, em seguida ao confronto com a armada holandesa, elevou à cabeça do Estado da Índia, com o título de governador, d. frei Aleixo de Meneses. Primeiro arcebispo de Goa até então a ocupar o governo do Estado da Índia, permaneceu no cargo por dois anos e meio. No exercício do mando temporal, acumulou experiência de governo, em período de crescente desestabilização das possessões portuguesas no Oriente com as singraduras de embarcações das companhias das Índias Orientais inglesa e holandesa, fundadas em 1600 e 1602 respectivamente. A prática de governança, unindo o trato dos dois poderes, seria reconhecida por Filipe III em futuro próximo, na nomeação a postos cimeiros da burocracia do reino: vice-rei (6/7/1614 a 11/7/1615) e primeiro presidente do Conselho de Portugal (1615-1617). ${ }^{74}$ Sem avançar no aprofundamento da trajetória político-administrativa de Aleixo de Meneses, cabe atentar para a relevância de um estudo da dimensão política e religiosa de sua atuação que escape ao relato edificante.

No tabuleiro do poder, a projeção política e o arranjo de privilégios estavam integrados a uma rede tutelar, essencial na movimentação nas carreiras eclesiásticas e civis. Por sua vez, a trama clientelar não apenas denota o prestígio pessoal como também move a definição de uma política eclesiástica no Estado da Índia que simultaneamente produz benefícios à atuação da ordem dos agostinhos.

No mapa religioso das partes do Oriente, d. frei Aleixo de Meneses propôs ao monarca uma divisão das ordens religiosas por áreas. Advertira acerca dos riscos de conceder o serviço a Deus à empresa de uma só religião. Para o "bem da cristandade" sugeriu uma distribuição de áreas de atuação entre franciscanos, jesuítas, dominicanos e agostinhos. O rei acatou o aviso e o reproduziu ao vice-rei d. Francisco da Gama em janeiro de 1598:

(...) pelo que ei por bem que daqui em diante vos com o dito Arcebispo e com os Inquisidores dessas partes façaes repartição das províncias entre os Religiosos para este efeito, e que quando parecer que em alguma delas devem entrar mais Ordens que uma, se ordene assim repartimos por distritos entre os Religiosos que houverem de entrar, para que cada

\footnotetext{
${ }^{74}$ OLIVAL, Fernanda, op. cit., p. 136.
} 
rev. hist. (São Paulo), n. 170, p. 107-141, jan.-jun., 2014 http://dx.doi.org/10.11606/issn.2316-9141.v0i170p107-141
Margareth de Almeida Gonçalves

A edificação da cristandade no Oriente português: questões em torno da Ordem dos Eremitas de Santo Agostinho no limiar do século XVII

uma Ordem acuda ao seu, e desta maneira se acodirá á necessidade que cada província tiver, e encomendo-vos que façais esta repartição na forma que neste capítulo vos digo.75

Por seu turno, em carta do mesmo ano, a 18 de dezembro, destinada a d. frei Agostinho de Jesus, expressou o intento de demarcar a ação dos agostinhos nas partes da Índia: “todo o meu desejo é alguma empresa particular, em que os nossos religiosos empreguem - afora as partes, em que estão de mistura, como os da Companhia em Japão, os franciscanos em Ceilão, e os dominicos em Soreth". E essa oportunidade foi confirmada no empenho em que se lançou para que os agostinhos atuassem na intermediação diplomática do rei da Pérsia, xá Abbas I. Em nova carta a Agostinho de Jesus, em 23 de dezembro de 1602, revelou a interferência que exerceu e o cuidado que teve na escolha dos nomes de religiosos agostinhos para o trato de questões da cristandade:

Pretenderam muito os da Companhia esta embaixada, por nas naus passadas lhes vir recado, que com as novas que chegaram a Roma, de ir embaixador do Хaa ao Papa, quizeram mandar Padres da Companhia, e se tratava disso.

Mas eu ordenei, que se désse a empresa e a embaixada à Ordem: e como se trata principalmente da christandade, pareceu-me dever ir o Padre Fr. Jeronymo da Cruz; que nesta terra era tido por santo, e tão desejoso de empresas, que estava já em Cochim para Bengala, e em sua companhia fr. Christovão, o castelhano, também grande servo de Deus. ${ }^{76}$

A abertura de um convento na capital da Pérsia, em Ispahan, envolveu a atuação dos agostinhos em um contexto político internacional que combinava atores diversos - persas, turcos e europeus (representados no papado, monarquia Habsburgo e nas novas companhias orientais de comércio inglesa e holandesa). A região foi central na condução da política da Igreja, presente no intento explicitado em cartas por Aleixo de Meneses, de conquista das "almas perdidas" da Igreja da Armênia - cristianizadas, segundo a tradição registrara, pelo apóstolo são Judas Tadeu -, e dos cristãos evangelizados pelo apóstolo "são João", na região de Baçorá ocupada pelos otomanos. A atuação do metropolita na Pérsia de xá Abbas I colocava em ação o empreendimento de universalização da cristandade pela inclusão dos cristãos

\footnotetext{
${ }^{75}$ Do rei a dom Francisco da Gama, escrita em Lisboa e assinada por Miguel de Moura, escrivão da puridade e membro da junta de governadores (5-7-1593 a janeiro de 1600), em 26 de janeiro de 1598, cf. RIVARA, J. H. da Cunha, op. cit., fascículo 3, p. 825, 826.

76 SENA, Bernardino José de. Memórias de Braga: contendo muitos e interessantes escriptos extrahidos e recopilados de differentes archivos, assim de obras raras como de manuscriptos ainda inéditos e descripção de pedras inscripcionaes. Braga: Imprensa católica, 1890, vol. III, p. 26, 59, respectivamente (grifos meus).
} 
cismáticos, entendidos por perdidos nos "erros nestorianos" das igrejas do Oriente. Um modelo da cristandade já perseguido por Aleixo de Meneses na realização do Sínodo de Diamper entre os cristãos do Kerala. O avanço dos agostinhos, iniciado no início do século XVII durante o arcebispado de Aleixo de Meneses, pelos espaços do golfo Pérsico, Armênia e Georgia, nos diversos contextos de guerras na região, culminaria na abertura de conventos na década de 1620 (Baçorá e Xiraz, em 1624; na cidade de Gori, no Gorgistão, em 1624). Acrescente-se ao peso das guerras a crescente disputa entre as missões do padroado de Portugal e os religiosos enviados pela Propaganda Fide.

Não obstante, pouco mais de um ano após a carta acima indicada, Aleixo de Meneses, no seu empenho pela introdução do rito latino à Igreja armênia, em nova epístola ao arcebispo de Braga, em 2 de fevereiro de 1604, manifestava o desejo de pessoalmente empreender a redução dos "cismáticos" à autoridade de Roma: "ir-lhes eu fazer um synodo, como foi na Serra - com maior fundamento e clareza da confutação de seus erros, para isto ficar fixo". ${ }^{77}$ Nessa ocasião, em seu lugar, foi mandado pela segunda vez à Pérsia o agostinho frei Antonio de Gouvêa. Saliente-se, no contexto das guerras perso-turcas, a migração em massa de armênios para a Pérsia promovida por xá Abbas I. Uma área vizinha a Ispahan abrigara os contingentes de armênios, a Nova Julfá.

O estudo de John Flannery sobre a atuação dos agostinhos na Pérsia aponta as dificuldades e os percalços no plano diplomático da mediação entre Roma, Filipe III e xá Abbas I, como também o contexto da fixação da atuação missionária na região. ${ }^{78}$ Nesse panorama, localiza-se o malogro de romanização da Igreja armênia. Não obstante, a cronística agostinha retém a fabricação de uma memória edificante do ato de submissão do patriarca armênio David IV (1587-1627) ao papa Paulo V em maio de 1607. A participação de ordens religiosas nas relações diplomáticas, como nesse exemplo dos agostinhos na Pérsia de xá Abbas I, encontra ainda, na experiência das embaixadas conduzidas pelos jesuítas na corte mogol de Akbar, indicadores de ações controversas, em que o proselitismo e a compulsão religiosa certamente assombreavam a dimensão cultural de compreensão da alteridade. Cabe assinalar, em ambos os casos, a valorização das disputas teológicas entre vertentes abraâmicas no ambiente das cortes persa e mogol, enredando-se as querelas políticas e as rivalidades comerciais entre impérios. Por sua vez, a busca pelos triunfos de guerras da cristandade na conversão de

\footnotetext{
${ }^{77}$ Idem, p. 80.

${ }^{78}$ FLANNERY, John, 2013, op. cit.
} 
membros de estirpe nobre conduzia os diversos embates pela fé, os quais alimentavam o ambiente católico. No nosso exemplo, a ilusão dos agostinhos na conversão do rei da Pérsia, xá Abbas I.

Se, inicialmente, o Sínodo de Diamper adiara a irrupção de conflitos e retivera a romanização das populações siríacas da costa do Malabar, as tensões religiosas, teológicas e políticas foram contumazes. A revolta geral de 1653 resultaria em nova divisão da comunidade siríaca entre católicos e ortodoxos. ${ }^{79}$ Acrescente-se ademais a frustrada tentativa agostinha de evangelização da ilha de Socotorá mais um dos pontos vinculados ao imaginário cristão do apóstolo são Tomé. A tenacidade de Aleixo de Meneses na universalização do modelo latino de cristandade forjou-se em um dos vetores de sua política religiosa com relação ao fortalecimento da atuação agostinha no Oriente.

A Congregação da Índia Oriental, nos 15 anos da mitra goesa de d. frei Aleixo de Meneses, valeu-se da intensificação da ação dos agostinhos em pontos chaves da política local e externa, como nos exemplos da ação missionária e diplomática na Pérsia. A fundação de espaços religiosos femininos - na defesa da "honra" e da "virtude" de mulheres - completou mais uma conquista de lugar de projeção dos agostinhos no Estado da Índia durante seu arcebispado. Deu ensejo à criação de dois recolhimentos e do mosteiro de Santa Mônica. Se o lançamento da pedra de fundação de um santuário de monjas devotas a Deus, em 1606, teve aplausos da República, a dedicação a santa Mônica e a administração agostinha foram conquistas do arcebispo, que, na defesa dos interesses da ordem dos eremitas, abandonou o intento anterior dos moradores da cidade de edificação de um mosteiro sob a invocação de santa Clara, sujeito à ordem de são Francisco. Na defesa da casa de professas agostinhas, segundo afirma frei Diogo de Santa Anna no sermão de 19 de dezembro 1627, em missa de celebração da nova igreja do mosteiro de Santa Mônica, Aleixo de Meneses enfrentou "grandes revoluções e tumul$\operatorname{tos}^{\prime \prime 80}$ da cidade que defendia a fundação de uma casa de clarissas.

\footnotetext{
79 SUBRAHMANYAM, Sanjay, 1998, op. cit., p. 39. Em leitura semelhante, Županov comenta que o "controverso" Sínodo de Diamper assinalou o começo do fim da subordinação dos cristãos de São Tomé ao catolicismo e da relação com os portugueses. Cf. ŽUPANOV, Ines. “One civility, but multiple religions": jesuit mission among St. Thomas christians in India (16th-17th centuries). Journal of Early Modern History, 9, 3-4, 2005, p. 319, http://dx.doi.org/10.1163/157006505775008473.

${ }^{80}$ Sermão em que o pe. frey Diogo de Sancta Anna pregou em 19 de dezembro de 1627 na dedicação da nova igreja do insigne mosteiro da gloriosa Sancta Monica da cidade de Goa.... ANTT/ML n. 87 - frei Diogo de Santa Anna. Apologia do insigne mosteiro de Santa Monica de Goa... (1633), fl 239v.
} 
Nos anos que antecederam à criação do novo mosteiro de monjas, a autoridade régia resistiu ao projeto, posição enunciada pelas cartas de 28 de janeiro de 1596 e $1^{\circ}$ de março de 1597 de Filipe II, esclarecendo "se será melhor ordenarem-se casas de recolhimento para donzelas enquanto não casarem (como há em Lisboa) e para mulheres casadas na ausência de seus maridos, de que outrossim me avisareis, sem em uma cousa e outra se dar nada a execução até terdes minha resposta do que houver por bem que faça". O arcebispo concedeu as orientações do soberano católico com a fundação dos recolhimentos de Nossa Senhora da Serra e de Maria Madalena, nos respectivos anos de 1605 e $1609 .{ }^{81}$ Contudo, já durante o reinado de Filipe III, no período em que acumulou a função de governador do Estado da Índia, durante a partida do vice-rei Martim Afonso de Castro para Malaca, como acima mencionado, lançou a fundação do mosteiro com o orago de Santa Mônica. Após a partida para o reino, em 31 de dezembro de 1610, permaneceu com zelo especial pelas casas de mulheres. A 8 de novembro de 1612, agora no reino e como arcebispo de Braga, em carta ao patriarca de Jerusalém, antigo coletor apostólico em Portugal e, desde 1602, mordomo-mor e prefeito do palácio papal em Roma, Fábio Biondi, fez pedido de graças e mercês aos recolhimentos e ao mosteiro de mulheres que fundara. Requeria graças a favor da aprovação dos estatutos do mosteiro de Santa Mônica. ${ }^{82}$ A correspondência entre Aleixo de Meneses e frei Diogo de Santa Anna, cura e administrador do mosteiro de monjas, demonstra a centralidade das instituições femininas na política eclesiástica do antigo arcebispo de Goa. Em carta, com data anterior à de Fábio Biondi, em 30 de março do mesmo ano, roga o consolo de "saber tudo, o que lá passa". 83

\footnotetext{
${ }^{81}$ Sobre a criação da rede de casas de mulheres em Goa por d. Frei Aleixo de Meneses no Índico, vejam-se: BETHENCOURT, Francisco, 1995, op. cit.; PINTO, Carla Alferes, op. cit., p. 279-309.

${ }^{82}$ Carta transcrita por ALONSO, Alejo de Meneses, O.S.A. (1559-1617) Arzobispo de Braga. I parte: Nombramiento, entrada y estancia en la diócesis (1612-1613). Archivo Agustiniano, Valladolid, 183, 1981, p. 66.

${ }^{83}$ D. frei Aleixo de Meneses. Capítulos das cartas que o arcebispo primaz de Braga escreveu ao padre Diogo de Santa Anna, confessor do Mosteiro de St. ${ }^{a}$ Mônica de Goa que deixou com seus poderes por confessor do seu mosteiro de Santa Monica de Goa, fl. 461. BA 47-VIII-15.
} 


\section{Considerações finais}

As quatro décadas entre a chegada da primeira missão agostinha à Ásia portuguesa, no ano de 1572, e a partida de d. frei Aleixo de Meneses de Goa para o Reino, em 1610, marcaram um período de transformações intensas no reino de Portugal, com desdobramentos no Estado da Índia. Os efeitos da morte de d. Sebastião no norte da África e a posterior crise dinástica, com o falecimento do cardeal-rei d. Henrique e a introdução de Portugal na órbita Habsburgo, assinalaram tempos de mudanças nos espaços europeus e asiáticos. No Índico, afirmaram-se o reino safávida na Pérsia e o império mogol no centro do subcontinente indiano, com extensões do Gujarate a Bengala. Por sua vez, os mares asiáticos foram singrados por holandeses, ingleses e franceses, desestabilizando contextos culturais e redes mercantis do comércio intrarregional e com os mercados europeus. Entrementes, não somente no legado das crônicas e memórias, como em parte da historiografia, o período Habsburgo tende a ser registrado como dos "anos dourados" e de apogeu da Ordem dos Eremitas de Santo Agostinho.

D. frei Agostinho de Jesus e d. frei Aleixo de Meneses fixaram uma política religiosa de disciplinamento e moralização cristã que, por um lado, combinou a atuação da monarquia Habsburgo e do papado e, por outro, assinalou a expansão e o fortalecimento dos agostinhos portugueses no Estado da Índia. As narrativas edificantes da tradição das crônicas da Ordem dos Eremitas de Santo Agostinho atentam ao nome dos dois. Hoje, a Igreja do Pópulo, contínua ao antigo colégio dos agostinhos localizado na cidade de Braga, exibe na capela-mor os túmulos de Agostinho de Jesus e Aleixo de Meneses, face a face, apoiados em leões e emoldurados pelos respectivos brasões de armas, Castro e Noronha. Provavelmente, a mesma disposição dos sepulcros desde o traslado do corpo de Aleixo de Meneses do convento de São Filipe em Madri no ano de 1621 (figuras 2 e 3). Igualmente, o painel do conjunto de azulejos da épica missionária agostinha na igreja do antigo Convento de Nossa Senhora da Graça de Lisboa, na outrora sala do capítulo, atualmente um espaço ocupado por uma creche, representa os dois ao centro da composição (figura 4). A ilustração exibe, sentados em cadeiras de espaldar alto, lado a lado, os dois antístites, o egrégio agostinho da mitra bracarence à esquerda e o notável de Goa à direita, portando flâmulas com as respectivas legendas: "praedicate evangelium omni creaturae", na sentença de Marcos 16, 15 ("ide por todo o mundo e pregai o Evangelho a toda criatura"); "ecce ego mitto vos sicut agnos", no versículo de Lucas 10, 3 ("Ide! Eis que 
vos envio como cordeiros entre lobos"). ${ }^{84}$ Na parte inferior do painel, dois religiosos tonsurados e ajoelhados apoiam-se em duas bandeirolas com os dizeres "Missão de África" e "Missão de Ásia", certificando os lugares dos dois metropolitas na cristianização das terras de conquista. ${ }^{85}$ No interior do recinto, amplos panos de azulejos, no mesmo padrão azul e branco da primeira metade dos Setecentos, destacam a ação de agostinhos nas missões do Oriente. Para além da palavra escrita, a imagética recorre a elementos da evangelização agostinha, na crença de possibilidades de uma civilização pela fé, que conectasse Ocidente e Oriente ao orbe cristão.

Recebido: 26/08/2013 - Aprovado: 18/03/2014

\footnotetext{
${ }^{84}$ Traduções no latim adaptadas de Bíblia de Jerusalém. Nova edição, revista e ampliada. São Paulo: Paulus, 2002, p. 1785 e 1807.

${ }^{85}$ Vejam-se as figuras 2, 3 e 4 dos túmulos na Igreja do Pópulo em Braga e do painel de azulejos do Convento da Graça. Na figura 4, a destacar a obturação dos olhos dos religiosos. A autoria da ação é desconhecida, embora se repita em todos os quadros de azulejos do Convento da Graça. As fotografias dos conjuntos de azulejos do Convento da Graça constam em AZEVEDO, Carlos Moreira, 2011, op. cit.
} 
rev. hist. (São Paulo), n. 170, p. 107-141, jan.-jun., 2014 http://dx.doi.org/10.11606/issn.2316-9141.v0i170p107-141
Margareth de Almeida Gonçalves

A edificação da cristandade no Oriente português: questões em torno da Ordem dos Eremitas de Santo Agostinho no limiar do século XVII

\section{Figura 1}

\section{Mapa dos conventos da Congregação da Índia Oriental (1572-1606)}

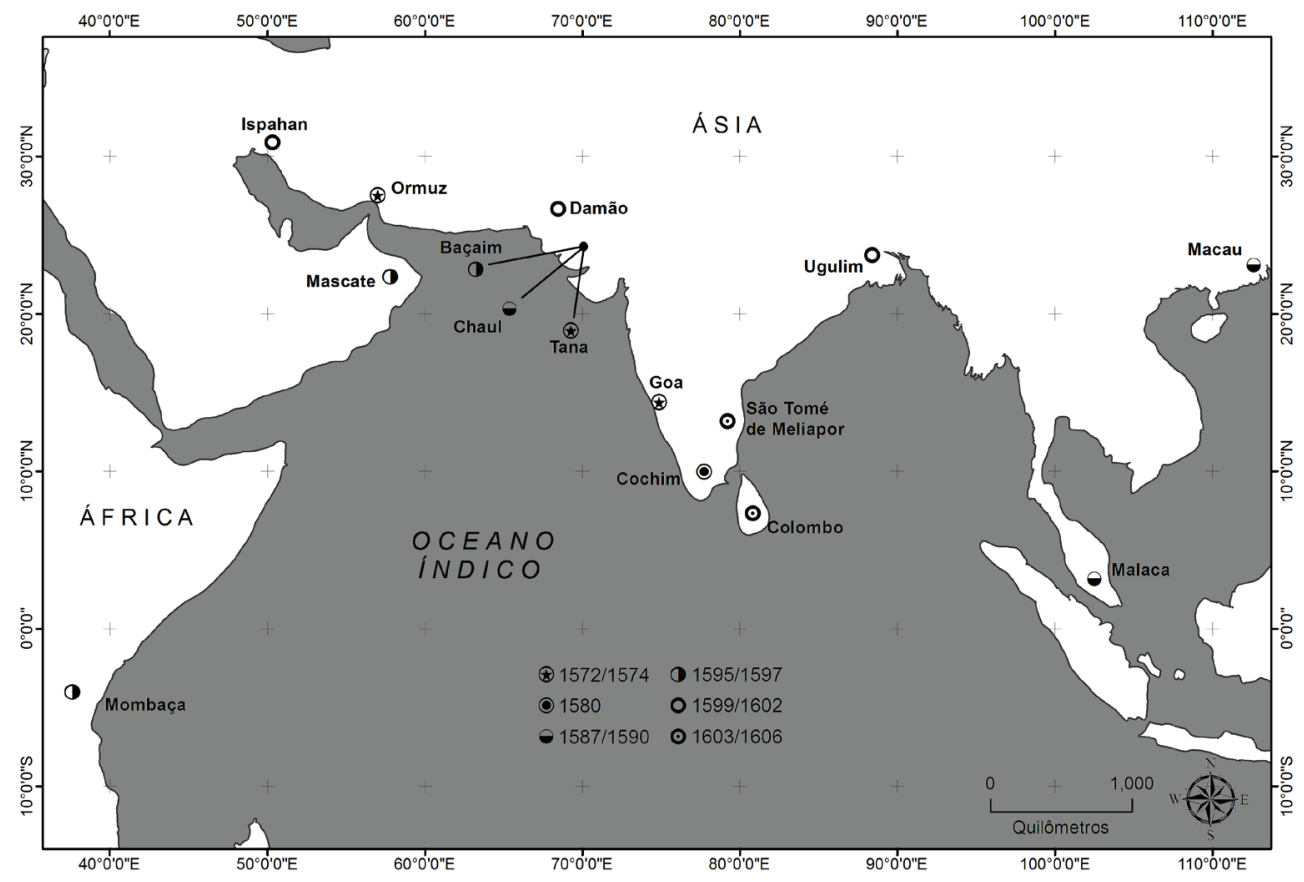




\section{Figura 2}

Túmulo de d. frei Agostinho de Jesus na Igreja do Pópulo-Braga

(fotografia da autora)

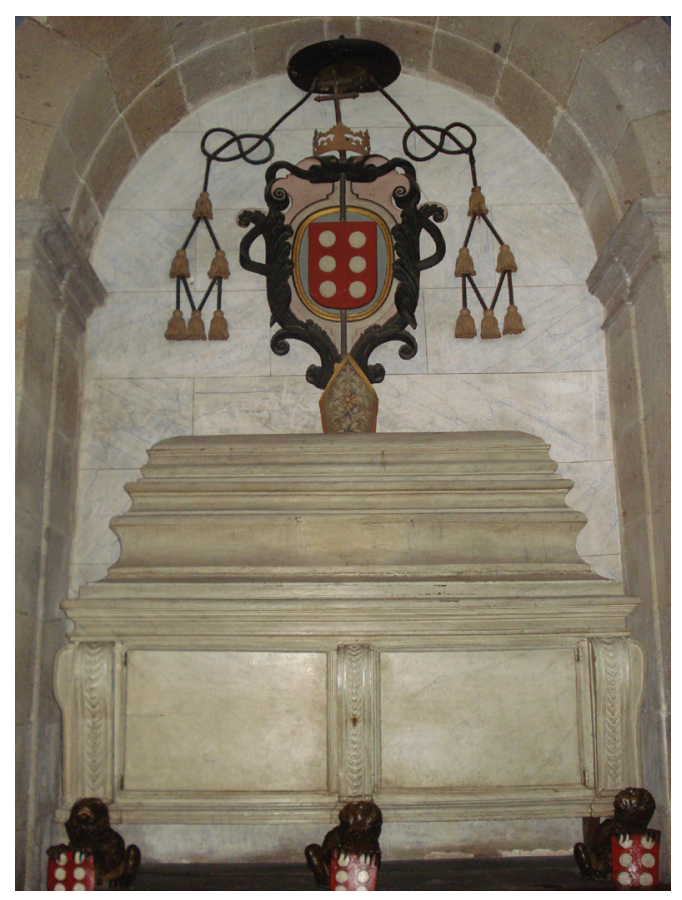

Figura 3

Túmulo de d. frei Aleixo de Meneses na Igreja do Pópulo- Braga

(fotografia da autora)

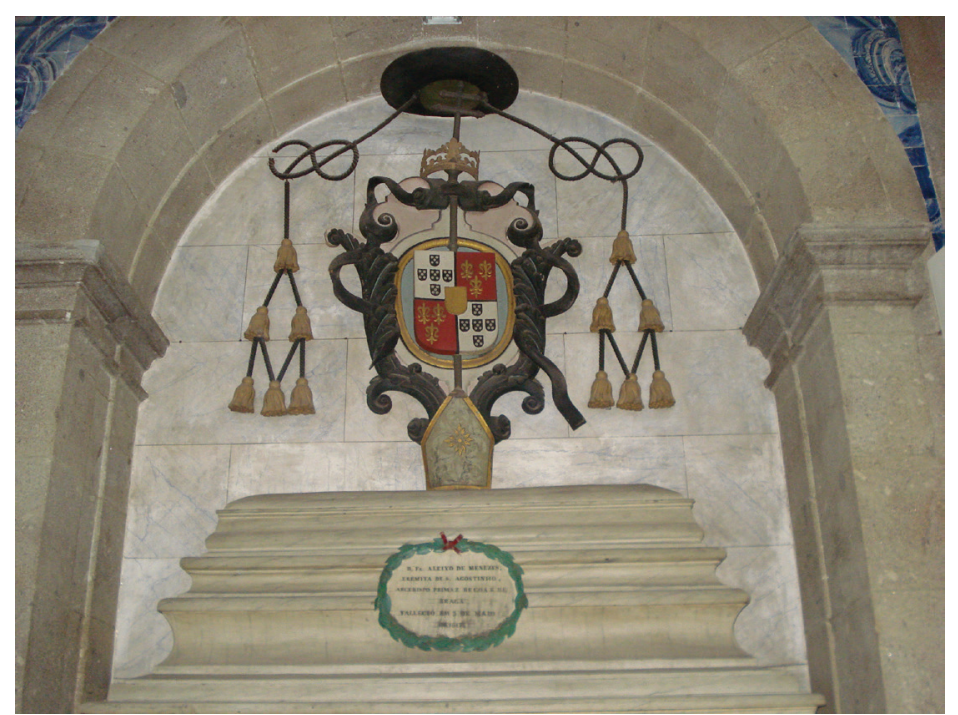


rev. hist. (São Paulo), n. 170, p. 107-141, jan.-jun., 2014 http://dx.doi.org/10.11606/issn.2316-9141.v0i170p107-141
Margareth de Almeida Gonçalves

A edificação da cristandade no Oriente português: questões em torno da

Ordem dos Eremitas de Santo Agostinho no limiar do século XVII

\section{Figura 4}

Agostinho de Jesus e Aleixo de Meneses, convento de Nossa Senhora da Graça de Lisboa

(fotografia de Alexandre Salgueiro / Arquivo do Patriarcado - Lisboa)

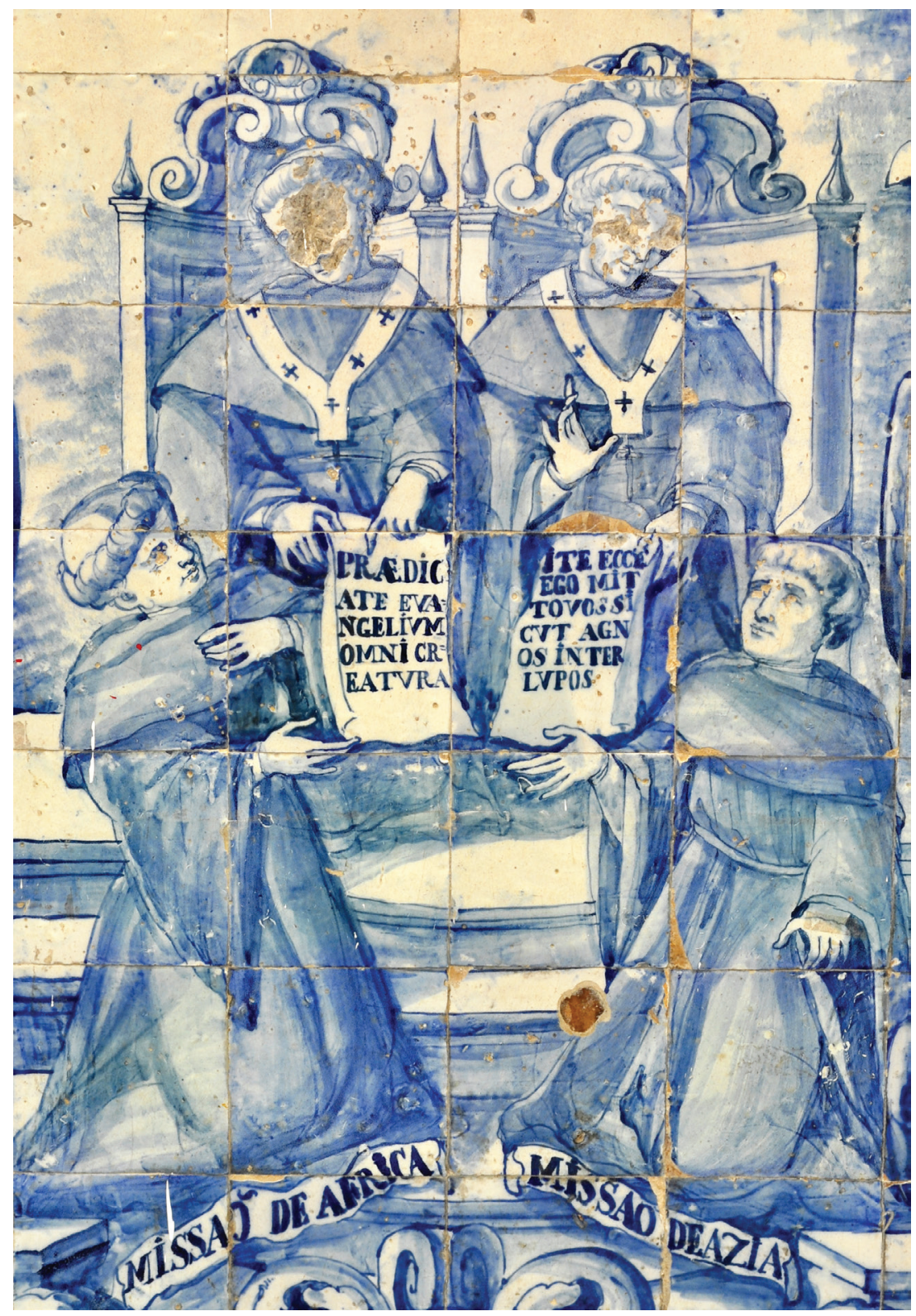


